\title{
Antioxidant and Cytotoxic Activities of Lactic Acid Bacteria on Colorectal Cancer WiDr Cell Line
}

\author{
Popi Hadi Wisnuwardhani ${ }^{*}$, Ratih Asmana Ningrum¹, Leggina Rezzy Vanggy ${ }^{2}$, Kusdianawati², \\ Apon Zaenal Mustopa ${ }^{1}$
}

${ }^{1}$ Research Center for Biotechnology, Indonesian Institute of Science LIPI, Jl. Raya Jakarta Bogor KM 46 Cibinong, Bogor 16911, Indonesia

${ }^{2}$ Sumbawa University of Technology, Sumbawa, Indonesia

\begin{abstract}
Colorectal cancer (CRC) is one of the leading causes of cancer and cancer-related deaths worldwide. Lactic acid bacteria (LAB) are bacteria that have potential activity as an inhibitor of the growth of colorectal cancer, and also has been widely used and was very useful for consumption. In our previous study, we isolated various LAB from Indonesian traditional fermented food. This study aims to determine the potential of LAB as an anticancer agent by determining the antioxidant activity and cytotoxicity assay of colon cancer in the WiDr cell line. This study used extracellular extract of various LAB. We use the Diphenylpicrylhydrazyl (DPPH) method to determine the antioxidant activity and 3-(4,5'dimethylihiazol-2-yl),2.5-di-phenyl-relrrzolium bromid (MTT) assay to study cytotoxicity activity. The viability cell staining also applied to detect unviable cells. The results informed that the highest antioxidant activity was shown by S.34 LAB with $81 \%$ activity. The $\mathrm{S} .34$ also showed cytotoxicity activity with $73 \%$ of WiDr viable cell at a concentration of $200 \mu \mathrm{g} / \mathrm{mL}$ of LAB extract. Based on the results of the study, it can be concluded that the S.34 LAB from Bekasam may inhibit the proliferation of WiDr cell lines and It had the highest antioxidant activity comparing to other LAB samples.
\end{abstract}

Keywords: Lactic Acid Bacteria, colorectal cancer, anticancer, antioxidant, WiDr cells.

\section{INTRODUCTION}

An instant lifestyle for the community and lack of exercise is one of the biggest factors causing cancer (Bishehsari, et al., 2014). One of the biggest rapidly cancer in the world is colorectal cancer (CRC). Based on WHO data in 2018, as the top three cancer, colorectal cancer reached 1.8 million cases with a $10.2 \%$ mortality rate (IARC, The Global Cancer Observatory 2019). In Indonesia the top three cancer are colorectal cancer, breast cancer and cervical cancer (Harpa, 2018).
Colorectal cancer refers to malignant tumors that found in the colon and rectum. The colon and rectum are part of the large intestine in the digestive system which is also called the gastrointestinal tract. Generally, the development of colorectal cancer is an interaction between environmental

Submitted: November 13, 2020

Revised: January 18, 2021

Accepted: January 25, 2021

*Corresponding author: popi002@lipi.go.id 
and genetic factors. It is strongly associated with weight gain, alcohol consumption, and the activity of free radicals in the body (Tatuhey, et al., 2012). Treatment of colorectal cancer can be performed by surgery, chemotherapy, and adjuvant therapy. However, these treatments have not been effective in curing colorectal cancer and are very expensive (Siregar, 2007). Therefore, an alternative treatment is needed to inhibit the development of colorectal cancer.

One of the potential treatment is using probiotic bacteria. Lactic acid bacteria (LAB) has some probiotic functions, such as adjusting the balance of intestinal flora, reducing serum cholesterol, inhibiting and reducing the risk of tumors, and revitalizing the immune system (Gupta, et al., 2018). LAB also can reduce symptoms of lactose intolerance symptoms, reduce constipation, eliminate inflammation, and prevent development of colorectal cancer (Zhong, et al., 2014). Lactobacillus has attracted a lot of attention for its potential probiotic effects on human health. Some lactobacilli have been shown that possessing ant oxidative activity and can decrease the risk of accumulation of reactive oxygen species during the ingestion of food (Zhang, et al., 2011). Several types of LAB that reported as anti colorectal cancer are $L$. Sakei GM3 (Avaiyarasi, et al., 2016), L. Casei BL23 (Jacauton, et al., 2017), Pediococcus Acidilactici (Villarante, et al., 2011) and L. Plantarum (Hu, et al., 2015).

Mustopa and Fatimah (2014) reported $\mathrm{LAB}$ isolates from Indonesian traditional food using 16S rRNA. The isolates were S34, S31, S12 Lactobacillus Plantarum (Bekasam); 2.12 Lactobacillus Casei (Goat milk); 1.13, R24, R31, DH1 Lactobacillus Fermentum (Curds); T8 Lactobacillus Plantarum (Sticky rice fermentation). In this study, we determine the potential of the LAB isolates as anticancer agents by determining the antioxidant activity and cytotoxicity assay in WiDr cell line.

\section{METHOD AND MATERIALS}

\section{Lactic Acid Bacteria Preparation}

Lactic acid bacterial isolates used were $\mathrm{S} 34$, S31, S12 (Lactobacillus Plantarum (Bekasam)) 2.12 (Lactobacillus casei (goat's milk), 1.13, R24, R31, DH1 (Lactobacillus Fermentum (Curd)), T8 (Lactobacillus Plantarum (Tape sticky rice).

\section{Sample Preparations}

Pre-culture of LAB isolates were inoculated as much as $5 \mu 1$ on $5 \mathrm{~mL}$ De Man, Rogosa and Sarpe, Himedia (MRS) media, incubated for 18-20 h. LAB isolates were then harvested (transferred to a $15 \mathrm{~mL}$ conical tube) and centrifuged at a speed of 10,000 rpm for 30 minutes. The supernatant is separated with pellets. Furthermore, the freeze-drying process is carried out by freezing the supernatant as much as $2 \mathrm{~mL}$ at $-80^{\circ} \mathrm{C}$ for 30 minutes and then drying it with a freeze dryer at $-55^{\circ} \mathrm{C}$ for 2 days. The freeze- dried sample was then dissolved with $10 \%$ Dimethyl sulfoxide (DMSO) (Applichem, Gatersleben, Germany) with a final concentration of $10 \mathrm{mg} / \mathrm{mL}$. For the 3-(4,5'dimethylihiazol-2-yl),2.5-di-phenylrelrrzolium bromid (MTT) assay, the extracted sample were dissolved in complete media (RPMI, Sigma St. Louis, Missouri, USA ) with the addition of $10 \%$ Fetal Bovine Serum (FBS) (Sigma, St. Louis, Missouri, USA) and 1\% Penicillin-Streptomycin supplements (Invitrogen, Carlsbad, California, USA) into several concentrations, namely $25 \mu \mathrm{g} /$ $\mathrm{mL}, 50 \mu \mathrm{g} / \mathrm{mL}, 100 \mu \mathrm{g} / \mathrm{mL}$, and $200 \mu \mathrm{g} / \mathrm{mL}$.

The LAB isolates was grown in $20 \mathrm{~mL}$ of liquid MRS media and incubated for 24-48 $\mathrm{h}$ at $37^{\circ} \mathrm{C}$. After incubation, the LAB isolates were then harvested (transferred to $50 \mathrm{~mL}$ tube centrifuge) and centrifuged at $6000 \mathrm{~g}$ for 10 minutes and the supernatant was stored at $-20^{\circ} \mathrm{C}$ for later use.

\section{Antioxidant Assay}

Twenty microliters of LAB supernatant were added into 96 well-plates with three replications. Diphenylpicrylhydrazyl (DPPH) (0.1 
mM DPPH in methanol) was then added as much as $180 \mu \mathrm{L}$ followed by incubation at room temperature under dark conditions for 30 minutes (Singh, et al. 2016). The absorbance of the sample was measured with a $540 \mathrm{~nm}$ ELISA reader. Data analysis was performed using the One-Way ANOVA test with a level of significant 0.05 .

\section{Cell Culture and Reagent}

WiDr human colon cancer cells (from mammalian cell culture laboratory, Indonesian Institutes of Sciences (LIPI), Indonesia) were thawed and washed with $9 \mathrm{~mL}$ of RPMI (Sigma) media containing penicillin (100 units $/ \mathrm{mL})$ and streptomycin $(100 \mathrm{mg} / \mathrm{mL})$ (Invitrogen). Cells were grown in the same media containing $10 \%$ FBS (Sigma) at $37^{\circ} \mathrm{C}$ and $5 \% \mathrm{CO}_{2}$. After $90 \%$ of confluency, the cells were washed with phosphate buffer saline ( $\mathrm{pH} 7.4$, Invitrogen) and detached with $500 \mu \mathrm{L}$ of triple express (-) non-phenol (Gibco, New York, USA) at $37^{\circ} \mathrm{C}$ for 3 minutes. The cells were divided and treated using four final concentration $(25 \mu \mathrm{g} / \mathrm{mL}, 50 \mu \mathrm{g} / \mathrm{mL}, 100 \mu \mathrm{g} / \mathrm{mL}$ and $200 \mu \mathrm{g} / \mathrm{mL})$ of nines extract of LAB samples (S34, S31, S12, 2.12, 1.13, R24, R31, DH1, T8).

\section{3-(4,5-dimethylthiazol-2-yl)-2,5-diphenyl tetrazolium bromide (MTT) Assay}

WiDr human colon cancer cells were seeded at a density of $1 \times 10^{5}$ in $10 \mathrm{~cm}$ cell dish to $15 \times 10^{3}$ cells/well. For the further assay, after confluences cells were seeded at a density of $1 \times 10^{4}$ cells/well. Each of $1 \times 10^{4}$ cells/well was seeded onto a 96-well plate and incubated for $48 \mathrm{~h}$ in a $\mathrm{CO}_{2}$ incubator. Following incubation, culture media was discarded, and MTT (Invitrogen) was added at a concentration of $0.5 \mu \mathrm{g} / \mu \mathrm{L}$. Cells were then incubated for $3 \mathrm{~h}$ and the medium was discarded. Formazan crystals formed at the bottom of the well were dissolved in $100 \mu \mathrm{L}$ of SDS $10 \%$. The cells were incubated overnight. The reaction was stopped by $0.01 \mathrm{M}$ $\mathrm{HCl}$ and dissolved formazan was measured at 540 $\mathrm{nm}$. The experiments were done in triplicates in three dependent experiments. Absorbance values were converted to the percentage of cell viability according to One-Way ANOVA with a significant level of 0.05 .

\section{Viabilty Staining}

Cell staining was performed as a previous study by Ningrum, et. al., (2015). Treated cells in 24 well plates were washed twice with $1 \mathrm{~mL}$ of PBS (Invitrogen) and stained with $500 \mu \mathrm{L}$ of 2 $\mu \mathrm{M}$ calcein $\mathrm{AM}$ and $4 \mu \mathrm{M}$ ethidium bromide (Life Technology). The cells were incubated at room temperature for 45 minutes and observed under a fluorescence microscope at $485 \mathrm{~nm}$ of excitation wavelength. The experiments were done in triplicates in three dependent experiments.

Tabel 1. Results of the LAB extract antioxidant activity assay.

\begin{tabular}{ccc}
\hline $\begin{array}{c}\text { Extract Lactic Acid } \\
\text { Bacteria Sample } \\
\text { (Ekstraseluler) }\end{array}$ & \multicolumn{2}{c}{ Incubation Time } \\
\cline { 2 - 3 } T8 & $\mathbf{2 4} \mathbf{h}$ & $\mathbf{4 8 ~ h}$ \\
S3 I & $72 \% \pm 0,013^{\mathrm{ab}}$ & $71 \% \pm 0,004^{\mathrm{ab}}$ \\
R24 & $70 \% \pm 0,003^{\mathrm{ab}}$ & $71 \% \pm 0,007^{\mathrm{ab}}$ \\
R3 I & $52 \% \pm 0,008^{\mathrm{a}}$ & $53 \% \pm 0,01 \mathrm{I}^{\mathrm{ab}}$ \\
S12 & $69 \% \pm 0,00 I^{\mathrm{ab}}$ & $63 \% \pm 0,008^{\mathrm{ab}}$ \\
I.13 & $80 \% \pm 0,014^{\mathrm{ab}}$ & $72 \% \pm 0,00 \mathrm{I}^{\mathrm{ab}}$ \\
S34 & $63 \% \pm 0,008^{\mathrm{ab}}$ & $77 \% \pm 0,008^{\mathrm{ab}}$ \\
DH I & $81 \% \pm 0,013^{\mathrm{ab}}$ & $63 \% \pm 0,013^{\mathrm{ab}}$ \\
$\mathbf{2 . 1 2}$ & $72 \% \pm 0,015^{\mathrm{ab}}$ & $73 \% \pm 0,013^{\mathrm{ab}}$ \\
Vitamin C & $70 \% \pm 0,004^{\mathrm{ab}}$ & $56 \% \pm 0,008^{\mathrm{ab}}$ \\
Media & $87 \% \pm 0,002^{\mathrm{b}}$ & $87 \% \pm 0,002^{\mathrm{b}}$ \\
\hline
\end{tabular}

Description: The figure followed by the same letter in the same column showed no significant difference in the one-way ANOVA test with a level of significant 0.05 . 


\section{RESULTS}

\section{Antioxidant Activity}

Antioxidant assay for extracellular extract of LAB within $24 \mathrm{~h}$ and $48 \mathrm{~h}$ incubation is obtained extracellular extract data showed LAB T8, S31, R31, S12, 1.13, S34, DH1 and 2.12 were significantly different from negative control of media and vitamin $C$ (Tabel. 1). This indicated that extracellular extracts of LAB had antioxidant activity against radical DPPH with a 24 and $48 \mathrm{~h}$ incubation period. The highest antioxidant activity of LAB extracellular extract in $24 \mathrm{~h}$ was $81 \%$ for LAB S34 (L. Plantarum from Bekasam) with $24 \mathrm{~h}$

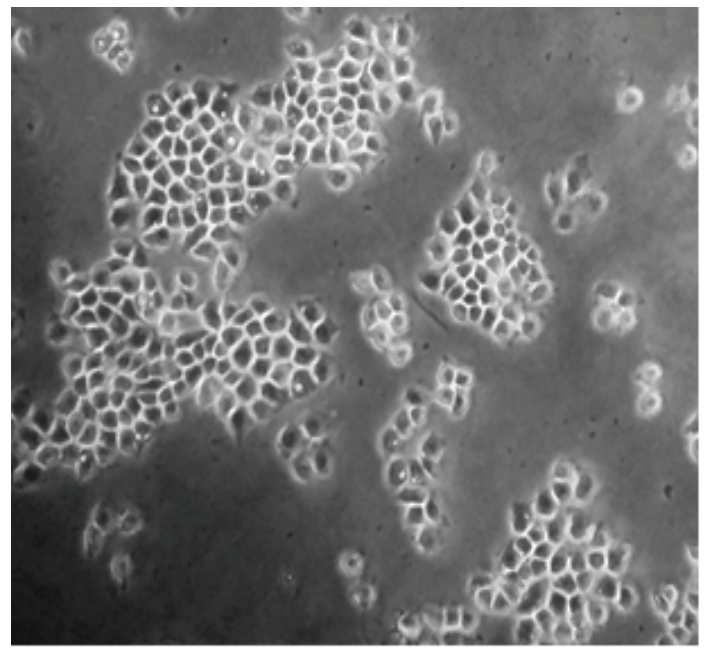

Figure 1. WiDr cells.

incubation time. Previous study reported that the antioxidant activity of extracellular extract of $L$. Plantarum LAB was above $80.0 \%$ (Hasim, et al. 2017).

The results of the antioxidant assay with 48 $\mathrm{h}$ incubation time from extracellular extracts of LAB T8, S31, R31, S12, 1.13, S34, DH1, and 2.12 were significantly different from the negative control of media and vitamin $\mathrm{C}$. This result that the LAB has antioxidant activity against free radicals DPPH. Extract LAB of 1.13 had the highest antioxidant activity of $77 \%$ while the LAB R24 had the lowest activity, namely R24 53\%. Based on the cross-test results with a level of significant 0.05 , it showed that there was no significant difference in the incubation treatment of the number of antioxidant compounds produced by extracellular extracts of LAB T8, S31, R31, S12, 1.13, S34, DH1, and 2.12.

\section{3-(4,5-dimethylthiazol-2-yl)-2,5-diphenyl tetrazolium bromide (MTT) Assay}

WiDr is a colorectal adenocarcinoma cell lines. It is epithelial and adherent cells that can be used as colorectal cancer model (Figure 1). We study the possibility of cytotoxic activity of nines extract LAB samples (S34, S31, S12, 2.12, 1.13, $\mathrm{R} 24, \mathrm{R} 31, \mathrm{DH} 1, \mathrm{~T} 8$ ) in four various concentration $(25 \mu \mathrm{g} / \mathrm{mL}, 50 \mu \mathrm{g} / \mathrm{mL}, 100 \mu \mathrm{g} / \mathrm{mL}$ and $200 \mu \mathrm{g} / \mathrm{mL})$. MTT assay was chosen due to its advantages as rapid and highly reproducible method.

The one-way ANOVA calculation results with a significant level of 0.05 showed that the results of the cytotoxicity as follows: at a concentration of $25 \mu \mathrm{g} / \mathrm{mL}$ extract S31 had the highest cytotoxicity activity, at a concentration of $50 \mu \mathrm{g} / \mathrm{mL}$ extract 2.12 has the highest cytotoxicity activity, at a concentration of $100 \mu \mathrm{g} / 2.12$ and S34 extracts had the highest cytotoxicity activity and at a concentration of $100 \mu \mathrm{g} / \mathrm{mL}$ (Table 2). This means that each $\mathrm{LAB}$ can reduce the viability of WiDr colon cancer cells at each concentration by $88 \%$, $86 \%, 79 \%$, and $73 \%$ and inhibits the viability of WiDr colon cancer cells by up to $12 \%, 14 \%, 21 \%$, and $27 \%$. The result showed in cytotoxicity assay that the highest value at each concentration was not significantly different from the positive control tamoxifen. Where the viability of colon cancer cells in tamoxifen positive control was $87 \%$ and inhibited the growth of colon cancer cells by $13 \%$. Kim et al., (2008) reported that $\mathrm{LAB}$ at a concentration of $200 \mu \mathrm{g} / \mathrm{mL}$ was able to inhibit the growth of Caco2 colon cancer cells by $36 \%$, LAB L. Plantarum inhibited the growth of cancer cells by up to $50 \%$ at 
Tabel 2. Viability of WiDr cells after cytotoxin assay with extract LAB.

\begin{tabular}{|c|c|c|c|c|c|}
\hline \multirow{2}{*}{$\begin{array}{l}\text { Extract Lactic } \\
\text { Acid Bacteria } \\
\text { Sample } \\
\text { (Ekstraseluler) }\end{array}$} & \multicolumn{4}{|c|}{ Concentration } & \multirow{2}{*}{$\begin{array}{c}I_{50} \\
(\mathrm{ppm})\end{array}$} \\
\hline & $25 \mu g / m L$ & $50 \mu \mathrm{g} / \mathrm{mL}$ & $100 \mu \mathrm{g} / \mathrm{mL}$ & $200 \mu \mathrm{g} / \mathrm{mL}$ & \\
\hline T8 & $111 \% \pm 0.164 \mathrm{~b}$ & $97 \% \pm 0.087 \mathrm{ab}$ & $85 \% \pm 0.079 a$ & $82 \% \pm\left. 0.04\right|^{a}$ & 1519.6 \\
\hline SI2 & $114 \% \pm 0.188^{b}$ & $104 \% \pm 0.028^{b}$ & $91 \% \pm 0.059 a$ & $81 \% \pm 0.064^{a}$ & 1329.4 \\
\hline R24 & $100 \% \pm 0.047 \mathrm{ab}$ & $96 \% \pm 0.026 \mathrm{ab}$ & $90 \% \pm 0.056^{a}$ & $81 \% \pm\left. 0.06\right|^{a}$ & 6155.7 \\
\hline R3 I & $105 \% \pm 0.075^{a b}$ & $90 \% \pm 0.068^{a b}$ & $87 \% \pm 0.054 a$ & $81 \% \pm 0.076^{a}$ & 3365.8 \\
\hline S3I & $88 \% \pm 0.0085 a$ & $93 \% \pm 0.105 \mathrm{ab}$ & $87 \% \pm 0.082^{a}$ & $82 \% \pm 0.110^{a}$ & |94804| \\
\hline 1.13 & $108 \% \pm 0.035 \mathrm{ab}$ & $89 \% \pm 0.040 \mathrm{ab}$ & $88 \% \pm 0.036^{a}$ & $78 \% \pm 0.112^{a}$ & 1634.6 \\
\hline DHI & $92 \% \pm 0.010 \mathrm{ab}$ & $87 \% \pm 0.054 a$ & $81 \% \pm 0.099 a$ & $82 \% \pm 0.097 a$ & 5795.8 \\
\hline S34 & $99 \% \pm 0.086 \mathrm{ab}$ & $89 \% \pm 0.095 a$ & $79 \% \pm 0.126^{a}$ & $73 \% \pm 0.100 a$ & I077.I \\
\hline 2.12 & $105 \% \pm 0.069 \mathrm{ab}$ & $86 \% \pm 0.073 a$ & $79 \% \pm 0.107 a$ & $74 \% \pm 0.119 a$ & 899.1 \\
\hline
\end{tabular}

Description: The figure followed by the same letter in the same column showed no significant difference in the one-way ANOVA test with a level of significant 0.05 .

a concentration of $500 \mu \mathrm{l} / \mathrm{mL}$ against colon cancer cells CaCo-2 (ER et al., 2015) and L. Plantarum A7 inhibits cell growth by up to $54 \%$ at a concentration of $2500 \mu \mathrm{g} / \mathrm{mL}$ against colon cancer cells HT-29 (Aliabadi, 2014).

\section{Viability Staining}

The results of viability staining of WiDr colon cancer cells that have been tested for cytotoxicity with fluorescent dye can be seen in Figure 2. We chose the 1.13, S34 and 2.12 to be monitored. The extract caused apoptosis in wiDr cell lines. There are two parameters of viable cells, intracellular esterase activity and plasma membrane integrity. We used Calcein AM and Ethidium Bromide III as fluorescent agent of cell staining. Calcein AM is a non-fluorescent cell-permeant that can be enzymatically converted into intensely fluorescent calcein. The polyanionic dye calcein is retained within the living cells producing green fluorescence. Ethidium bromide III is excluded by the intact plasma membrane of live cells and is $40 \%$ brighter than Ethidium bromide I (Ningrum et al., 2015).

\section{DISSCUSSION}

Antioxidant activity is a mechanism possessed by antioxidant compounds to delay, inhibit, and prevent the oxidation process of fat so that it can protect cells from oxidative damage by free radicals such as singlet oxygen, superoxide, peroxyl radicals, hydroxyl radical, and peroxynitrite (Zhang et al., 2011 ). The reaction between DPPH and antioxidant compounds occurs due to dehydrogenation of antioxidant molecules so that DPPH changes to DPPHn where $n$ shows the number of $\mathrm{H}$ atoms received by DPPH from antioxidants, DPPH will be purple and DPPHn has a color that decreases in concentration closer to yellow (Nenadis and Tsimidou, 2010).

Based on the cross-test results with a level of significant 0.05 , it was showed that there is no significant difference in the incubation time and treatments of the antioxidant compounds produced by extracellular extracts of LAB T8, S31, R31, S12, 1.13, S34, DH1 and 2.12, The antioxidant compounds that play a role in antioxidant activity can be acid compounds produced by LAB. The antioxidants produced by L. Plantarum, namely L-3(4-hydroxyphenyl) lactic acid (HPLA) and L-indol-3-lactic acid (Suzuki, et al., 2013; Guo, et al., 2013).

Antioxidant activity in LAB is due to the presence of peptides produced from extracellular extracts (Pihlanto, et al., 2006). The antioxidant compounds produced in the extracellular extract of LAB can be in the form of the breakdown of pro- 
a

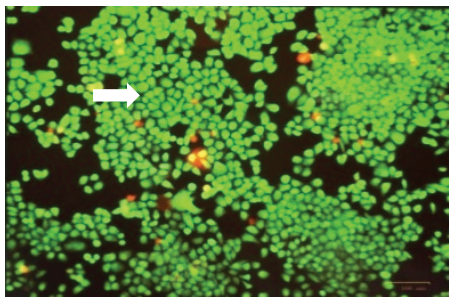

C

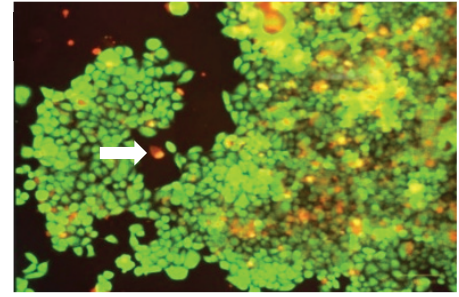

b

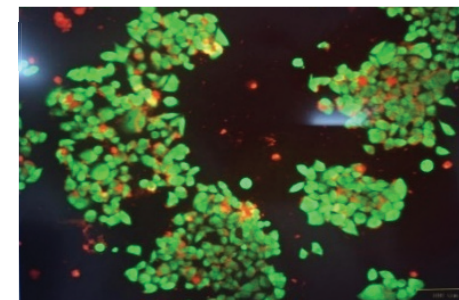

d

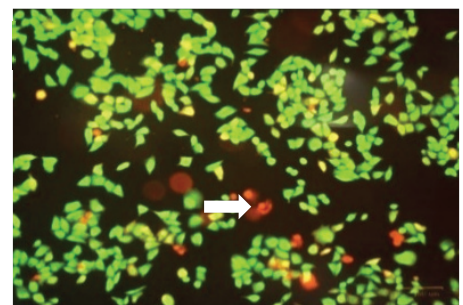

Figure 2. Viability staining of WiDr cells (100x magnification). (a) Cell control; (b) WiDr cells with treated extracellular extract LAB for 2.12; (c) WiDr cells with treated extracellular extract LAB for S34; (d) WiDr Cells with treated extracellular extract LAB for 1.13. Green: life cell; Red: dead cell.

teins from cellular products secreted by bacteria with the highest antioxidant activity found in the supernatant of LAB. Antioxidant activity in LAB is due to the presence of peptides produced from extracellular extracts (Pihlanto, et al., 2006). The antioxidant compounds produced in the extracellular extract of LAB can be in the form of the breakdown of proteins from cellular products secreted by bacteria. Peptides that have biological activity can be produced through enzymatic hydrolysis and fermentation (Shahidi and Zhong, 2008). The fermentation of $\mathrm{LAB}$ produces peptides with sizes below 3000 Da which play a role in free radical binding activity (Pihlanto, et al., 2006). Peptide size can be associated with accessibility to a larger antioxidant assay system for small peptides and amino acids than for large peptides and proteins (intracellular) because larger peptides are difficult to dissolve in test solvents such as methanol which is used in the DPPH antioxidant assay.

WiDr colon cancer cells are unique in their gene arrangement. The advantages of WiDr cells as a research model are that they have an efficiency of up to $100 \%$ in the process of tumor cell proliferation, are easy to culture, a short doubling-time of $15 \mathrm{~h}$, and a high plating efficiency of $51 \%$. In this study, we used WiDr cells with $80 \%$ confluence, where cells have grown on almost all dish surfaces. According to Ruutu, et al. (2004), when the cell has more than $80-85 \%$ confluent and the cell fills all the walls of the dish, it can trigger intracellular mechanisms that affect protein synthesis and degradation and change the expression of certain genes in cells through contact inhibition. Contact inhibition is a process of restraining cell growth when cells come into contact with each other, as a result, normal cells will stop growing when forming a monolayer in a dish (Seluanov, et al., 2009), so this study refers to previous studies regarding the number of cells used. The number of cells used for this cytotoxicity test is $1 \times 10^{4}$ cells per well in 96 well plates, therefore at least the cells must reach $80 \%$ confluence.

Cytotoxicity assay used to select the various isolate that has potential as anticancer agents based on the ability of cells to survive due to the presence of toxic compounds. The ability of cells to survive can be interpreted as not loss of cell proliferation and can be measured by increasing cell numbers, increasing the number of proteins, or synthesized DNA (Dhanalakshmi, et al., 2016). The MTT assay is based on the ability to viability cells to reduce MTT salts that are yellow and dissolve 
into purple formazan salts (Kusuma, et al., 2010). The formazan crystal purple color is read by absorbance using an ELISA reader. Formazan crystals formed are proportional to the number of living cells.

The best cytotoxicity activity was from the LAB S34 extract at a concentration of $200 \mu \mathrm{g} /$ $\mathrm{mL}$ which was able to inhibit the viability of colon cancer cells with $73 \%$ of viable cells. Inhibition of WiDr colon cancer cell viability can be caused by apoptosis (death). Extracellular extract of LAB has high cytotoxicity activity and able to inhibit the viability of WiDr colon cancer cells. Based on research conducted by Kahouli, et al. (2013) that extracellular extracts of LAB have a preventive effect on cancer cells due to the effects of organic acids and exopolysaccharide roles namely rEPS (released exopolysaccharides) and cbEPS (cell bound exopolysaccharides). Anticancer activity was found in peptidoglycan produced by $L$. casei, polysaccharides and glycoproteins found in the Lactobacillus culture supernatant. LAB has a mechanism to inhibit the growth of colon cancer cells, namely suppressing tumor cell development and boosting the immune system, suppressing procarcinogenic enzyme activity and eliminating mutagenic compounds, and inducing the production of cytokines such as TNF- $\alpha$ (Tumor Necrosis Factor) (Kim, et al., 2008). Some LABs such as $L$. rhamnosus (ATCC53103), L. plantarum (VTT), Lactococcus lactis (ARH74), and Bifidobacterium animalis in a live state have the potential to induce the production of TNF- $\alpha$ and interleukin-6 (IL-6). TNF- $\alpha$ is a cytokine produced by macrophages and is responsible for various signaling events in cells that lead to necrosis or apoptosis and is also important for resistance to infection and cancer (Idriss and Naismisth, 2000).

\section{CONCLUSION}

The S34 L. Plantarum extracellular extract has potential use as an anticancer agent with high antioxidant activity. Additional assay should be performed to determine the anticancer activity.

\section{ACKNOWLEDGEMENTS}

This research was supported by a Competitive program 2018 grant of the Indonesian Institute of Sciences (LIPI), Indonesia. The authors would like to thank to Dr. Adi Santoso from Laboratory Protein-Based Therapeutic and Vaccine in Research Center for Biotechnology LIPI for supporting this work.

\section{REFERENCES}

Aliabadi, H.S., Mohammadi, F., Fazeli, H. and Mirlohi, M., 2014, Effects of Lactobacillus plantarum A7 with probiotic potential on colon cancer and normal cells proliferation in comparison with a commercial strain, Iranian Journal of Basic Medical Sciences, 17, 815-819.

Avaiyarasi, N.D., Ravindran, A.D., Venkatesh, P. and Arul, V., 2016, In Vitro Selection, Characterization and Cytotoxic Effect of Bacteriocin of Lactobacillus sakei GM3 Isolated From Goat Milk, Food Control, 69, 124-133.

Bishehsari, F., Mahdavinia, M., Vacca, M., Malekzadeh, R. and Mariani-Costantini, R., 2014, Epidemiological transition of colorectal cancer in developing countries: environmental factors, molecular pathways, and opportunities for prevention, World J Gastroenterol, 20(20), 6055-6072.

Dhanalakshmi, J., Selvi, S. V. and Selvi, S., 2016, Anticancer and Cytotoxic Potential of Ethanolic extract of Tribulus terrestris on Hela cell lines, International Research Journal of Bioloy Science, 5(6), 37-42.

ER, S., Koparal, A.T. and Kivanc, M., 2015, Cytotoxic Effects of Various Lactic Acid Bacteria on Caco-2 cells, Turkish Journal of Biology, 39, 23-30.

Guo, Y., Pan, D., Li, H., Sun, Y., Zeng, X. and Yan, B. 2013, Antioxidant and immunomodulatory 
activity of selenium exopolysaccharide produced by Lactococcus lactis subsp. lactis, Food chemistry, 138(1), 84-89.

Gupta, R., Jeevaratnam, K. and Fatima, A., 2018, Lactic Acid Bacteria: Probiotic Characteristic, Selection Criteria, and its Role in Human Health (A Review), Journal of Emerging Technologies and Innovative Research, 5(10), 411-424.

Harpa (Harapan Terpadu), 2018, Yayasan Kanker Indonesia. Edisi 2/April. Kanker Kolorektal. http: / /yayasankankerindonesia.org/storage/ articel//8862ae79118c0477547330d56fdd408a. pdf.

Hasim, Mustopa, A.Z., Andrianto, N., Fatimah, and Faridah, D.N., 2017, Antioxidant Production of Lactic Acid Bacteria Isolated From Indonesian Traditional Fermented Buffalo Milk (Dadih), IOSR Journal of Pharmacy and Biological Sciences (IOSR-JPBS), 12(5), 76-82.

Hu, J., Wang, C., Ye, L., Yang, W., Huang, H., Meng, F., Shi, S. and Ding, Z., 2015, Anti-Tumour Immune Effect of Oral Administration of Lactobacillus Plantarum to CT26 Tumour-Bearing Mice, Journal of biosciences, 40(2), 269-279.

IARC (International Agency for Research on Cancer), 2018, http://gco.iarc.fr/today/data/factsheets/populations/360-indonesia-fact-sheets. pdf.

Idriss, H.T. and Naismith, J.H., 2000, TNFa and the TNF receptor superfamily: Structure-function relationship (s), Microscopy research and technique, 50(3), 184-195.

Isolauri, E., 1998, Lactic acid bacteria and immune modulation, Lactic acid bacteria-microbiology and functional aspects, 255-268.

Jacouton, E., Chain, F., Sokol, H., Langella, P. and Bermudez-Humaran, L.G., 2017, Probiotic Strain Lactobacillus Casei BL23 Prevents Colitis-Associated Colorectal Cancer, Frontiers in immunology, 1553.

Kahouli, I., Duchesneau, C.T. and Prakash, S., 2013, Probiotics in Colorectal Cancer (CRC) with Emphasis on Mechanisms of Action and Current Per- spectives, Journal of Medical Microbiology, 62, 1107-1123.

Kim, Y., Lee, D., Kim, D., Cho, J., Yang, J., Chung, M., Kim, K. and Ha, N., 2008, Inhibition of proliferation in colon cancer cell lines and harmful enzyme activity of colon bacteria by Bifidobacterium adolescentis SPM0212, Archives of pharmacal research, 31(4), 468.

Kusuma, A.W., Nurulita, N.A. and Hartanti, D., 2010, Efek Sitotoksik dan Antiproliferatif Kuersetin Pada Sel Kanker Kolon WiDr, Pharmacy, 07(03), 107-122.

Mustopa, A.Z. and Fatimah, 2014, Diversity of Lactic Acid Bacteria isolated from Indonesia National fermented Foods, Microbiology Indonesia, 8(2), 48-57.

Ningrum, R.A., Wardhani, P.H., Santoso, A. and Herawati, N., 2015, Antiproliveration Activity of Recombinant Human Interferon Alpha 2B on Estrogen Positive Human Breast Cancer MCF-7 Cells Line, Indonesian Journal Pharmacy, 26(2), 86-93.

Nenadis, N. and Tsimidou, M.Z., 2010, Assessing the activity of natural food antioxidants: Oxidation in Foods and Beverages and Antioxidant Applications: Understanding Mechanis ms of Oxidation and Antioxidant Activity, Technology and Nutrition, 332-367.

Pihlanto, A., 2006, Antioxidative peptides derived from milk proteins, International Dairy Journal, 16(11), 1306-1314.

Ruutu, M., Johansson, B., Grenman, R., Syrjänen, K. and Syrjänen, S., 2004, Effect of confluence state and passaging on global cancer gene expression pattern in oral carcinoma cell lines Anticancer research, 24(5A), 2627-2632.

Shahidi, F. and Zhong, Y., 2008, Bioactive Peptides, Journal of AOAC International, 91, 914-931.

Seluanov, A., Hine, C., Azpurua, J., Feigenson, M., Bozzella, M., Mao, Z., Catania, K.C. and Gorbunova, V., 2009, Hypersensitivity to contact inhibition provides a clue to cancer resistance of naked mole-rat, Proceedings of the National 
Academy of Sciences, 106(46), 19352-19357.

Suzuki, Y., Kosaka, M., Shindo, K., Kawasumi, T., Kimoto-Nira, H. and Suzuki, C., 2013, Identification of antioxidants produced by Lactobacillus plantarum, Bioscience, biotechnology, and biochemistry, 121006.

Singh, P., Baranwal, M. and Reddy, S.M., 2016, Antioxidant and cytotoxic activity of carotenes produced by Dunaliella salina under stress, Pharmaceutical Biology, 54(10), 2269-2275.

Tatuhey, W.S., Nikijuluw, H. and Mainase, J., 2012, Karakteristik Kanker Kolorektal Di RSUD Dr. $M$ Haulussy Ambon Periode Januari, Molucca Medica, 4(2), 150-157.

Villarante, K.I., Elegado, F.B., Iwatani, S., Zendo, T.,
Sonomoto, K. and Guzman, E.E., 2011, Purification, Characterization and In Vitro Cytotoxicity of The Bacteriocin from Pediococcus Acidilactici K2a2-3 Against Human Colon Adenocarcinoma (HT29) and Human Cervical Carcinoma (HeLa) Cells, World Journal of Microbiology and Biotechnology, 27(4), 975-980.

Zhang, S., Liu, L., Su, Y., Li, H., Sun, Q., Liang, X. and Lv, J., 2011, Antioxidative activity of lactic acid bacteria in yogurt, African Journal of Microbiology Research, 5(29), 5194-5201.

Zhong, L., Zhang, X. and Covasa, M., 2014, Emerging Roles of Lactic Acid Bacteria in Protection Against Colorectal Cancer, World Journal of Gastroenterology, 20(24), 7878. 
overexpression of ER $\beta$ can reduce proliferation in cancer cells (Strom, et al., 2004; Hartman, et al., 2009; Nilsson, et al., 2011). This research focuses on estrogen receptor beta agonists because it has the potential as an antitumor therapy agent by activating beta subtypes and preventing proliferative effects on cancer. Ligands that are included as estrogen receptor beta-agonists that have the potential activity to inhibit the proliferation of glioma cells are DPN (Diarylpropionitrile), MFF101, Liquiri-tigenin, and LY500307 (comparison drug (Erteberel)) (Sareddy, et al., 2012; Sareddy and Vadlamudi, 2015). Erteberel is one of the agonists ER $\beta$ that has high potential in reducing glioma cell proliferation and it can penetrate the blood-brain barrier (Sareddy, et $a l ., 2016)$. The discovery of a specific agonists ER $\beta$ provided naturally has opened the development of new therapies through the estrogen receptor beta to prolong survival in cancer patients (Sareddy and Vadlamudi, 2015).

Based on the research by Sareddy, et al. (2012) show that ER $\beta$ pathway activation is a potential therapeutic target for glioma because ER $\beta$ agonists are under clinical trials and are well tolerated with fewer side effects. The use of ER $\beta$ as a therapeutic agent can be extended to clinical use and is predicted to be a new class of drugs for treating glioma. Future studies examining the mechanism of ER $\beta$ in cancer progression will be useful for maximizing treatment using ER $\beta$ natural ligands (Sareddy and Vadlamudi, 2015). The purpose of this study was to determine the activity of Heliannuols on estrogen receptor beta and the lack of information on estrogen receptor betaagonists as therapeutic agents in cancer patients, encouraging researchers to compile this study.

\section{MATERIALS AND METHODS}

\section{Software}

This research uses Chem Bio Draw Ultra 12.0 application, Avogadro, pkCSM online tool, Protox II online tool (accessed on January 2020), and Molegro Virtual Docker 6 (Lisensi expires on: January 01, 2099).

\section{Target and Template Selection}

The target of this research is the estrogen receptor beta 2I0G from Protein Data Bank (https:// www.rcsb.org). The test compounds of this research are Heliannuol A, B, C, D, and E where the SMILES code from Chem Bio Draw 12.0 and the Erteberel SMILES code from PubChem.

\section{Prediction of Physicochemical, Pharmacokinetic, and Toxicity Properties}

Prediction of physicochemical properties using the pkCSM online tool and the Protox II online tool by entering the SMILES code of the compound. The prediction of physicochemical properties is based on Lipinski's rules and the ability of compounds to penetrate the brain barrier membrane. Lipinski's rules use to evaluate compounds that have pharmacological activity with predictable physical and chemical properties as drug candidates for humans. While the prediction of pharmacokinetic properties using the online pkCSM tool is based on the absorption, distribution, metabolism, and excretion parameters. Toxicity prediction using the pkCSM online tool and the Protox II online tool based on several parameters and toxicity classes according to the Globally Harmonized System (GHS).

\section{Molecular Docking}

Molecular docking using Molegro Virtual Docker 6.0 to know the interaction between the test compound and the receptor. 2D structures of Heliannuol A, B, C, D, and E were drawn using Chem Draw Ultra 12.0 and to know the SMILES code of the test compounds then 3D structures were made using Avogadro and energy minimization was performed. Validation of molecular docking ER $\beta$ (2I0G) using Molegro Virtual Docker 6.0 and a docking simulation process was also performed. Validation of molecular docking result is the Root 
Mean Square Deviation (RMSD), the docking simulation process can be run if the RMSD value was less than $2 \AA$. The parameters used in docking simulation include rerank score, bond distance, and type of interaction.

\section{RESULTS}

\section{Prediction of Physicochemical Properties and Toxicity}

Prediction of physicochemical properties using Lipinski rules of five with several parameters includes molecular weight, the partition coefficient of octanol/water $(\log \mathrm{P})$, Hydrogen Bond Donors (HBD), and Hydrogen Bond Acceptors (HBA). Topological Polar Surface Area (TPSA) also a parameter to determine compound can penetrate the brain barrier membrane (Kelder, et al., 1999). The physicochemical test was used to predict that the compound has good permeability, high absorption, and can penetrate the blood-brain barrier. The results of physicochemical properties, the ability of compounds to penetrate the brain barrier membrane, and toxicity are shown in Table 1.

The results of physicochemical prediction show that all compounds comply with Lipinski rules, it can be predicted that all compound easy to absorption and has good permeability. The result of TPSA showed that all compounds have a TPSA value of less than 80 , it can be predicted that all compounds could penetrate the brain barrier membrane (Hughes, 2008). Heliannuol A, B, and C are in toxicity class 4 with Lethal Dose $\left(\mathrm{LD}_{50}\right) 300-2000$ $\mathrm{mg} / \mathrm{kg}$. Heliannuol D and Erteberel are in toxicity class 5 with $\mathrm{LD}_{50} 2000-5000 \mathrm{mg} / \mathrm{kg}$. Heliannuol A, B, C, D, E, and Erteberel were predicted to be nontoxic in the AMES Mutagenic test, not toxic in the Hepatotoxicity test, and did not cause skin irritation in the Skin Sensitization test.

\section{Prediction of Pharmacokinetic Properties}

Prediction of pharmacokinetic properties is based on the prediction of absorption, distribution, metabolism, and excretion (ADME) using the

Table 1. Prediction of physicochemical and toxicity.

\begin{tabular}{|c|c|c|c|c|c|c|c|c|c|c|c|c|}
\hline \multirow[b]{2}{*}{ Compound } & \multicolumn{6}{|c|}{ Physicochemical Properties } & \multicolumn{5}{|c|}{ Toxicity } & \multirow{2}{*}{$\begin{array}{c}\text { Lipinsk } \\
\text { Rules of } \\
\text { Five }\end{array}$} \\
\hline & $M W^{*}$ & $\log P^{*}$ & $\mathrm{HBA}^{*}$ & HBD* & Torsion* & TPSA** & $\begin{array}{c}\text { AMES } \\
\text { Mutagenic* }\end{array}$ & Hepatotoxicity* & $\begin{array}{c}\text { Skin } \\
\text { Sensitization* }\end{array}$ & $\operatorname{LD}_{50} * *$ & $\begin{array}{c}\text { Class of } \\
\text { Toxicity** }\end{array}$ & \\
\hline Heliannuol A & 250.338 & 3.11622 & 3 & 2 & 0 & 49.69 & No & No & No & 860 & 4 & Yes \\
\hline Heliannuol B & 248.322 & 2.8922 & 3 & 2 & I & 49.69 & No & No & No & 482 & 4 & Yes \\
\hline Heliannuol C & 248.322 & 2.89222 & 3 & 2 & I & 49.69 & No & No & No & 500 & 4 & Yes \\
\hline Heliannuol D & 250.338 & 3.1162 & 3 & 2 & I & 49.69 & No & No & No & 2148 & 5 & Yes \\
\hline Heliannuol E & 248.322 & 2.89222 & 3 & 2 & 2 & 49.69 & No & No & No & 500 & 4 & Yes \\
\hline Erteberel & 282.339 & 4.1152 & 3 & 2 & I & 49.69 & No & No & No & 5000 & 5 & Yes \\
\hline
\end{tabular}

Description: *pkCSM online tool; **Protox II online tool.

pkCSM online tool. The results of the prediction of pharmacokinetic properties are shown in Table 2.

The result from the prediction of pharmacokinetic properties shows ADME of the compound, in this research shows that all compound is predicted to have good intestinal absorption with the value is more than $80 \%$ (Chander, et al., 2017). According to the pkCSM online tool page website (http://biosig.uni-melb.edu.au/pkcsm/theory), the compound has a high skin permeability if the $\log$ value of $\mathrm{Kp}>-2.5 \mathrm{~cm} / \mathrm{h}$, and all compound are predicted have high skin permeability. Caco2 permeability is good if the Papp value $>0.90 \mathrm{~cm} / \mathrm{s}$ and all compounds are predicted to have good permeability. Heliannuol $\mathrm{C}$ and $\mathrm{E}$ do not include as Pgp substrates, then they are not predicted to be 
Table 2. Prediction of pharmacokinetic properties.

\begin{tabular}{|c|c|c|c|c|c|c|c|}
\hline \multirow{2}{*}{\multicolumn{2}{|c|}{ Prediction Category }} & \multicolumn{6}{|c|}{ Result } \\
\hline & & Heliannuol A & Heliannuol B & Heliannuol C & Heliannuol D & Heliannuol E & Erteberel \\
\hline \multirow{8}{*}{ 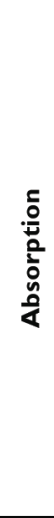 } & $\begin{array}{c}\text { Absorption in } \\
\text { intestine (\%) }\end{array}$ & 90.904 & 91.276 & $91.826^{* *}$ & 90.8 & $91.759^{+}$ & $93.474^{*}$ \\
\hline & $\begin{array}{l}\text { Skin Permeability } \\
\left(\text { Log } K_{p} \mathrm{~cm} / \mathrm{h}\right)\end{array}$ & -3.243 & -3.192 & $-3.285^{+}$ & -3.159 & $-3.35^{* *}$ & -2.751 \\
\hline & Caco-2 & & & & & & \\
\hline & Permeability(Log & $1.283^{*}$ & 1.3 & 1.242 & $1.312^{* *}$ & 1.248 & 1.248 \\
\hline & Ppap in $10^{-6} \mathrm{~cm} / \mathrm{s}$ ) & & & & & & \\
\hline & $\begin{array}{l}\text { P-glycoprotein } \\
\text { substrate }\end{array}$ & Yes & Yes & $\mathrm{No}^{++}$ & Yes & $\mathrm{No}^{++}$ & Yes \\
\hline & $\begin{array}{l}\text { P-glycoprotein I } \\
\text { inhibitor }\end{array}$ & No & No & No & No & No & No \\
\hline & $\begin{array}{l}\text { P-glycoprotein II } \\
\text { inhibitor }\end{array}$ & No & No & No & No & No & No \\
\hline \multirow{3}{*}{ 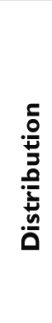 } & Vdss (Log L/kg) & 0.092 & 0.156 & 0.082 & $0.166^{* *}$ & $0.135^{+}$ & $0.378^{*}$ \\
\hline & $\begin{array}{c}\text { BBB Permeability } \\
\text { (Log BB) }\end{array}$ & $0.295^{* *}$ & -0.024 & $0.233^{+}$ & -0.023 & 0.221 & -0.062 \\
\hline & $\begin{array}{l}\text { CNS Permeability } \\
\text { (Log PS) }\end{array}$ & -2.769 & -2.793 & $-1.942^{* * *}$ & -2.787 & -2.042 & $-1.745^{*}$ \\
\hline \multirow{7}{*}{ 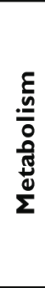 } & CYP2D6 substrate & No & No & No & No & No & No \\
\hline & CYP3A4 substrate & No & No & No & No & No & Yes $^{++}$ \\
\hline & CYPIA2 inhibitor & No & No & No & No & No & Yes $^{++}$ \\
\hline & CYP2CI9 inhibitor & No & No & No & No & No & Yes $^{++}$ \\
\hline & CYP2C9 inhibitor & No & No & No & No & No & Yes $^{++}$ \\
\hline & CYP2D6 inhibitor & No & No & No & No & No & No \\
\hline & CYP3A4 inhibitor & No & No & No & No & No & Yes $^{++}$ \\
\hline \multirow{2}{*}{ 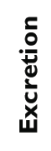 } & $\begin{array}{l}\text { Total Clearance } \\
\text { (Log } \mathrm{m} / / \mathrm{min} / \mathrm{kg} \text { ) }\end{array}$ & 0.947 & $1.009^{+}$ & $1.085^{* *}$ & 0.946 & $1.08^{* *}$ & 0.005 \\
\hline & $\begin{array}{l}\text { Renal OCT2 } \\
\text { substrate }\end{array}$ & No & No & No & No & No & No \\
\hline
\end{tabular}

Description: Vdss (Volume of Distribution at Steady State); BBB (Blood Brain Barrier); CNS (Central Nervous System); CYP2D6 (Cytochrome P2D); CYP3A4 (Cytochrome 3A4); CYP1A2 (Cytochrome 1A2); CYP2C19 (Cytochrome 2C19); CYP2C9 (Cytochrome 2C9); Renal OCT2 (Renal Organic Cation Transporter 2). *The highest value of comparative drugs; ${ }^{* *}$ The highest value of the first test compound; +The second highest value of the test compound; ++Different result from other.

removed from the target cell (Chakraborty and Ramakrishnan, 2016). Heliannuol A, B, C, D, E, and Erteberel are not included as Pgp I and II inhibitors, it predicts that the compound did not inhibit the work of the Pgp substrate (Robert and Jarry, 2003). The distribution volume of the compound is declared low if the Log Vdss value $<-0.15$ and high if the Log Vdss value $>0.45$, all compound has good distribution volume. Compounds with $\log \mathrm{BB}>0.3$ can penetrate the brain barrier membrane while compounds with $\log \mathrm{BB}<-1$ cannot be well distributed in the brain. Compounds with Log PS $>-2$ are considered to be able to penetrate CNS while $\log \mathrm{PS}<-3$ are considered unable to pene- 
Indonesian Journal of Cancer Chemoprevention, February 2021

ISSN: 2088-0197

e-ISSN: 2355-8989

iscce. III]CIC

Table 3. Validation of molecular docking.

\begin{tabular}{ccccc}
\hline \multirow{2}{*}{ Receptor } & \multicolumn{3}{c}{ RMSD (A) } & Average \pm SD (A) \\
\cline { 2 - 4 } & Replication I & Replication II & Replication III \\
\hline 2I0G (A) & 0.4429 & 0.7535 & 0.7794 & $0.6586 \pm 0.1872$ \\
210G (B) & 0.5947 & 0.8566 & 0.8296 & $0.7603 \pm 0.1440$ \\
\hline
\end{tabular}

trate CNS. All compound is predicted to penetrate the brain barrier and central nervous system. Heliannuol A, B, C, D, E are predicted not to be part of the CYP substrate or inhibitor then the compound is predicted to be metabolized without the help of cytochrome enzymes and does not inhibit the work of CYP 450. Whereas Erteberel is predicted to include CYP3A4 substrate and inhibitors of CYP1A2, CYP2C19, CYP2C9, CYP2C9, and CYP3A4. Heliannuol $\mathrm{C}$ is predicted to have a faster excretion process than other compounds because if the CLTOT value is higher then the excretion is faster (Hardjono, et al., 2018). Heliannuol A, B, C, D, E, and Erteberel are predicted to not include Organic Cation Transporter 2 (OCT2) substrate then the compound is predicted to be excreted without OCT2 substrate, OCT plays an important role in cationic drugs (Koepsell, 2015).

\section{Validation of Molecular Docking System}

RMSD is a parameter for receptor validation. The validation of molecular docking process is carried out by docking between the native ligand and the receptor, if the results obtained are less than 2 , it can be predicted that poses receptor with the native ligand is valid (Ruswanto, 2015). Validation of molecular docking result are shown in Table 3.

Validation of molecular docking result in table 3 show that the receptor has two ligands and the $2 \mathrm{I0G}(\mathrm{A})$ ligand has a smaller RMSD value than the $2 \mathrm{I} 0 \mathrm{G}(\mathrm{B})$ ligand.

\section{Docking Molecular and Interaction of Amino Acid}

The docking simulation process uses several parameters including the MolDock Score, Rerank Score, and $\mathrm{H}$ bond. The results of
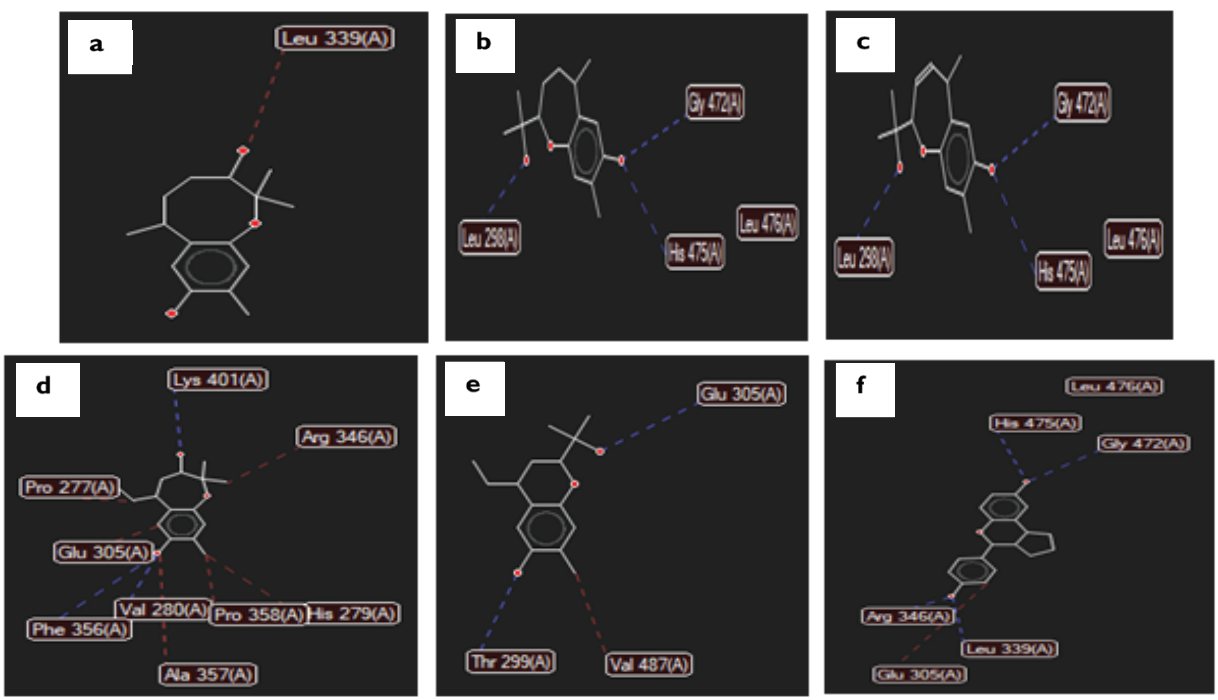

Figure 1. Interaction of amino acids between (a) Heliannuol A, (b) Heliannuol B, (c) Heliannuol C, (d) Heliannuol D, (e) Heliannuol E, (f) Erteberel on ERB with red color as steric bond and blue color as hydrogen bond. 
Table 4. Interaction of amino acid and rerank score.

\begin{tabular}{|c|c|c|c|}
\hline Compound & $\begin{array}{c}\text { Hidrogen Bond and } \\
\text { Distance }(\boldsymbol{A})\end{array}$ & $\begin{array}{c}\text { Steric Bond and } \\
\text { Distance }(A)\end{array}$ & $\begin{array}{c}\text { Rerank Score } \\
\text { (kcal/mol) }\end{array}$ \\
\hline \multirow[t]{2}{*}{ Heliannuol A } & - & Leu $339(3.09)^{*}$ & -69.988 \\
\hline & Gly 472 (2.6I) & & \\
\hline \multirow[t]{5}{*}{ Heliannuol B } & His $475(3.32)^{*}$ & - & -72.313 \\
\hline & Leu 298 (2.79) & & \\
\hline & & Arg $346(2.70)^{*}$ & \\
\hline & $\mid$ ve $40 \mid(300)$ & Pro 358 (2.89) & \\
\hline & Lys $401(3.00)$ & Pro 277 (2.79) & \\
\hline \multirow[t]{4}{*}{ Heliannuol C } & Val 280 (3.10) & His $279(2,99)$ & -78.532 \\
\hline & Phe $356(2.98)$ & Ala 357 (3.15) & \\
\hline & & Glu $305(2,93)^{*}$ & \\
\hline & Gly 472 (2.60) & & \\
\hline \multirow[t]{2}{*}{ Heliannuol D } & His $475(3.18)^{*}$ & - & -70.814 \\
\hline & Leu 298 (2.84) & & \\
\hline \multirow{4}{*}{ Heliannuol E } & Glu $305(2.60)^{*}$ & Val $487(3.12)$ & -80245 \\
\hline & Thr 299 (3.1I) & & \\
\hline & His $475(2.69)^{*}$ & & \\
\hline & Gly 472 (3.37) & & \\
\hline \multirow[t]{3}{*}{ Erteberel } & Leu 339 (3.10) & Glu 305 (2.99)* & -97.857 \\
\hline & $\operatorname{Arg} 346(2.82)^{*}$ & & \\
\hline & Glu 305 (3.29)* & & \\
\hline
\end{tabular}

Description: *Amino Acid of Heliannuols that same with Erteberel.

molecular docking are showed by the interaction of amino acids and rerank scores are shown in Figure 1 and Table 4.

In Figure 1 and Table 4 are show that Heliannuol A has a steric bond with the amino acid Leu 339, Heliannuol B has a hydrogen bond Gly 472, Leu 298, His 475, Heliannuol C has a hydrogen bond Lys 401, Val 280, Phe 356, and a steric bond Arg 346, Pro 358, Pro 277, His 279, Ala 357, Glu 305. Heliannuol D has hydrogen bonds Gly 472, His 475, Leu 298, Heliannuol E has hydrogen bonds Glu 305, Thr 299, and steric bonds Val 487. Whereas Erteberel has bonds hydrogen His 475, Gly 472, Leu 339, Arg 346, Glu 305 and steric bonds Glu 305.

\section{DISCUSSION}

The purpose of this research was to predict interactions, toxicity, and physicochemical properties of Heliannuol A, B, C, D, and E compounds using in silico study as anticancer. Prediction of physicochemical properties and toxicity is obtained by submitting the compound SMILES code into the pkCSM online tool and the ability to penetrate the brain barrier is obtained from the Protox II online tool. Heliannuol A, B, C, D, and E can be predicted easily absorbed and have good permeability because have a molecular weight less than $500, \log \mathrm{P}$ values are less than 5, HBD expressed by the number of $\mathrm{OH}$ groups and $\mathrm{NH}$ is less than 5 , and HBA which is expressed with some $\mathrm{O}$ and $\mathrm{N}$ atoms less than 10 (Lipinski, et al., 2001). All compounds have a TPSA value less than $80 \AA$, it can be predicted that the compound can penetrate the brain barrier membrane (Hughes, 2008). Heliannuol $\mathrm{A}, \mathrm{B}$, and $\mathrm{C}$ are in toxicity class 4 which means fatal if ingested with $\mathrm{LD}_{50} 300-2000 \mathrm{mg} / \mathrm{kg}$. Heliannuol D and Erteberel are in toxicity class 5 which means it might be dangerous if swallowed with $\mathrm{LD}_{50}$ 2000-5000 mg/kg (El-Din, et al., 2016). All compounds also were predicted to be non-toxic 
in the AMES Mutagenic test, not toxic in the liver, and did not cause skin irritation. Pharmacokinetic properties are used to determine the absorption, distribution, metabolism, and excretion of the test compound. The result of pharmacokinetic shows that Heliannuols have high absorption and can penetrate the brain barrier membrane where these compounds are expected as therapy in glioma patients. Besides, Heliannuol $\mathrm{C}$ and $\mathrm{E}$ are not included in the Pgp substrate then these compounds are predicted not to be removed from the cell and are expected to increase the therapeutic effect of the compound. This prediction is expected to be used as an additional prediction regarding the effects of the compound in the body before proceeding to the in vivo and in vitro tests.

This research shows that the receptor has two active sides that bind with the native ligand is 2I0G(A) and 2I0G(B). Ligand 2I0G(A) has a smaller RMSD value than $2 \mathrm{IOG}(\mathrm{B})$, it can be predicted that the active side of the receptor for the docking simulation is $2 \mathrm{I0G}(\mathrm{A})$. The docking process can be performed if the receptor has RMSD value $\leq 2$ and the RMSD value from ligand $2 \mathrm{I} 0 \mathrm{G}(\mathrm{A})$ is $0.6586 \AA$. Prediction of molecular docking between Heliannuol $\mathrm{A}, \mathrm{B}, \mathrm{C}, \mathrm{D}$, and $\mathrm{E}$ with estrogen receptors $\beta(\mathrm{ER} \beta)$ show that Heliannuol $\mathrm{E}$ has the lowest energy with a rerank score of $-69.988 \mathrm{kcal} / \mathrm{mol}$ and predicted to have the most stable bond among other Heliannuols and predicted have the greatest activity. And if the result of the rerank score (the value of bond energy) is lower (more negative), the bond between the ligand and receptor is more stable, and the more stable bond between the ligand and receptor than the activity is high (Hardjono, 2012).

The result of amino acid interaction from this research includes hydrogen and steric bond. Heliannuols have the same several amino acids with an amino acid of the Erteberel by hydrogen bonds. Hydrogen bonds are non-covalent bonds that play a role in the biological activity produced (Muchtaridi, et al., 2018; Wijaya, et al., 2003). Erteberel bind to amino acid His 475, Glu 305, and Arg 346 with hydrogen bonds, a compound that binds with that amino acid can be classified as an ER $\beta$ agonist. Estrogen receptor beta agonist bind to amino acid Glu 305, Arg 346, His 475 (Meegan and Lloyd, 2003). Heliannuols have the same amino acid with an amino acid of the Erteberel by hydrogen bond, but Heliannuol A doesn't bind to amino acid His 475, Glu 305, and Arg 346. From the result of this study, it can be predicted that Heliannuol B, C, D, E have the same function with the Erteberel as an ER $\beta$ agonist. Prediction of physicochemical, pharmacokinetic, and toxicity from Heliannuols are predicted to have high absorption, good permeability, can penetrate the blood-brain barrier, and toxicity in classes 4 and 5 . The docking result of Heliannuols is not good than the Erteberel because Erteberel still has the lowest rerank score than Heliannuols.

\section{CONCLUSION}

The conclusion from the research shows that Heliannuols have the same amino acid with the Erteberel, then can be predicted that Heliannuols have the same effect on estrogen receptor beta. When looked at its physicochemical, pharmacokinetics, and toxicity, Heliannuols has high absorption, can penetrate the brain barrier membrane, has good permeability and toxicity is in grades 4 and 5. However, the rerank score of Erteberel is still lower than Heliannuols. And for further research, it is recommended that Heliannuols be tested on other receptors to produce a lower rerank score of test compound than comparison compound.

\section{REFERENCES}

Ceccarini, 2004, Essential Oil Composition of Helianthus Annus L. Leaves and Heads of Two Cultivated Hybrids 'Carlos and Florom 350, Industrial Crops and Products.

Chakraborty, P. and Ramakrishnan, M., 2016, Role of P-Glycoprotein in Chemotherapeutic Drug Resistance and Mechanisms of Pump Deactivation to Overcome MDR in Cancer Cells A Critical Review, 
Frontiers in Biomedical Science, 1(2), 8.

Chander, S., Tang, C.R., Al-Maqtari, H.M., Jamalis, J., Penta, A., Hadda, T.B., Sirat, H.M., Zheng, Y.T. and Sankaranarayanan, M., 2017, Synthesis and Study of Anti-HIV-1 RT Activity of 5-Benzoyl-4Methyl-1,3, 4,5-Tetrahydro-2h-1,5-Benzodia-zepin-3-One Derivates, Bioorg Chem, 72, 74-79.

El-Din, H.M.A., Loutfy, S.A., Fathy, N., Elberry, M.H., Mayla, M.A., Kassem, S. and Naqvi, A., 2016, Molecular Docking Based Screening of Compounds Against VP40 Ebola Virus, Bioinformation, 12(3), 192-196.

Ghantous, A., Gali-Muhtasib, H., Vuorela, H., Saliba, N.A. and Darwiche, N., 2010, What Made Sesquiterpene Lactones Reach Cancer Clinical Trials?, Drug Discovery Today, 15(15-16), 668-678.

Hardjono, S., 2012, Modiikasi Struktur 1-(Benzoiloksi) Urea Dan Hubungan Kuantitatif Struktur Aktivitas Sitotoksiknya, Surabaya: Universitas Airlangga.

Hardjono, S., Siswandono, and Andayani, R., 2017, Evaluation of N-Benzoylthiourea Derivatives as Possible Analgesic Agents by Predicting Their Hysicochemical and Pharmacokinetic Properties, Toxicity, and Analgesic Activity, Indonesian Journal of Biotechnology, 22(2), 76-85.

Hartman J., Edvardsson, K., Lindberg K., Zhao, C., Williams, C., Strom, A. and Gustafsson, J-A., 2009, Tumor Repressive Functions of Estrogen Receptor Beta in SW480 Colon Cancer Cells, Cancer Res, 69(15), 6100-6106.

Heffron, T.P., Wei, B., Olivero, A., Staben, S.T., Tsui, V. and Do, S., 2011, Rational Design of Phosphoinositide 3-Kinase A Inhibitors That Exhibit Selectivity Over the Phosphoinositide 3-Kinase B Isoform, J. Med. Chem, 54(22), 7815-7833.

Hughes, R.G., 2008, Patient Safety and Quality: An Evidence Base Handbook for Nurses, Rochville MD: Agency for Healthcare Research and Quality Publication.

Kelder, J., Grootenhuis, P.D., Bayada, D.M., Delbressine, L.P. and Ploemen, J.P., 1999, Polar
Molecular Surface as A Dominating Determinant for Oral Absorption and Brain Penetration of Drugs, Pharmaceutical Research, 16(10), 15141519.

Koepsell, H., 2015, Role of Organic Cation Transporters in Drug-Drug Interaction, Expert Opin Drug Metab Toxicol, 11(10), 1619-1633.

Kuntala, N., Telu, J.R., Anireddy, J.S. and Pal, S., 2017, A Brief Overview on Chemistry and Biology of Benzoxepine, Letters in Drug Design and Discovery, 14(9), 1-13.

Lipinski, C.A., Lombardo, F., Dominy, B.W. and Feeney, P.J., 2001, Experimental and Computational Approaches to Estimate Solubility and Permeability in Drug Discovery and Development Settings, Advanced Drug Delivery Reviews, 46(1-3), 3-26.

Macias, F.A., Molinillo, J.M.G., Varela, R.M. and Torres, A., 1994, Structural Eludation and Chemistry of A Novel Family of Bioactive Sesquiterpenes: Heliannuols, J. Org. Chem, 59, 8261-66.

Macias, F.A., Varela, R.M., Torres, A. and Molinillo, J.M.G., 2000, Potential Allelopathic Activity of Natural Plant Heliannes: A Proposal of Absolute Configuration and Nomenclature, Journal of Chemical Ecology, 26(9), 2173-2186.

Macias, F.A., Torres, A., Galindo, J.L.G., Varela, R.M., Alvarez, J.A. and Molinillo, J.M.G., 2002, Bioactive Terpenoids from Sunflower Leaves CV. Peredovick, Phytochemistry, 61(6), 687-692.

Meegan, M.J. and Lloyd, D.G., 2003, Advances in The Science of Estrogen Receptor Modulation, Curr Med Chem, 10(3), 181-210.

Muchtaridi, Yanuar, A., Megantara, S. and Purnomo, H., 2018, Kimia Medisinal: Dasar Dasar Dalam Perancangan Obat Edisi Pertama, Jakarta: Prenada Media Group.

Nilsson S. and Gustafsson J.A., 2011, Estrogen Receptors: Therapies Targeted to Receptor Subtypes, Clin Pharmacol Ther, 89(1), 44-55.

Ren, W., Qiao Z., Wang H., Zhu L., and Zhang L., 2003, Flavonoids, Promising Anticancer Agents, 
Med Res Rev. 23(4), 519-534.

Robert, J. and Jarry, C., 2003, Multidrug Resistance Reversal Agents, Journal Med Chem., 46(23), 4805-4817.

Ruswanto, 2015, Molecular Docking Empat Turunan Isonicotinohydrazide Pada Mycobacterium Tuberculosis Enoyl-Acyl Carrier Protein Reductase (InhA), Jurnal Kesehatan Bakti Tunas Husada: Jurnal Ilmu-ilmu Keperawatan, Analis Kesehatan dan Farmasi, 13(1), 135-141.

Saini, S., and Sharma, S., 2011, Helianthus Annuus (Asteraceae): A Review, International Journal of Pharma Professional's Research, 2(4), 381386.

Sareddy, G.R., Nair, B.C., Gonugunta, V.K., Zhang, Q-g., Brenner, A., Brann, D.W., Tekmal, R.R. and Vadlamudi, R.K., 2012, Therapeutic Significance of Estrogen Receptor B Agonists in Gliomas, Molecular Cancer Therapeutics, 11(5), 1174-82.

Sareddy, G.R. and Vadlamudi, R.K., 2015, Cancer Therapy Using Natural Ligands That Target Estrogen Receptor Beta, Chinese Journal of
Natural Medicines, 13(11), 801-7.

Sareddy, G.R., Li, X., Liu, J., Viswanadhapalli, S., Garcia, L., Gruslova, A., Cavazos, D., et al., 2016, Selective Estrogen Receptor B Agonist LY500307 as a Novel Therapeutic Agent for Gliolastoma, Scientific Report, 6, 24185.

Siswandono, 2011, Studi Pemodelan Molekul Interaksi Beberapa Turunan Penisilin Dengan Reseptor DD-Transpeptidase Dari Streptomyces R61(1PWC), Airlangga Journal of Pharmacy, 9(2), 33-41.

Strom, A., Hartman, J., Foster, J.S., Kietz, S., Wimalasena, J. and Gustafsson, J-A., 2004, Estrogen Receptor Beta Inhibits 17Beta-Estradiol-Stimulated Proliferation of the Breast Cancer Cell Line T47D, Proc Natl Acad Sci USA, 101(6), 1566-1571.

Wijaya, K., Tahir, I. and Harnowo, 2003, Studi Mekanisme Migrasi Proton Ganda Pada Struktur Supermolekul Asam Asetat-Air dan Asam Asetat-Ammoniak dengan Metode Ab Initio, Indonesian Journal of Chemistry, 3(2), 102-110. 


\title{
Pentagamaboronon-0-Sorbitol Induces Apoptosis through Elevation of Reactive Oxygen Species in Triple Negative Breast Cancer Cells
}

\author{
Ratna Dwi Ramadani ${ }^{1}$, Rohmad Yudi Utomo ${ }^{1,2}$, Adam Hermawan ${ }^{1,3}$, Edy Meiyanto ${ }^{1,3^{*}}$ \\ ${ }^{1}$ Cancer Chemoprevention Research Center (CCRC), Faculty of Pharmacy, Universitas Gadjah Mada, \\ Sekip Utara Yogyakarta 55281 \\ ${ }^{2}$ Laboratory of Medicinal Chemistry, Department of Pharmaceutical Chemistry, Faculty of Pharmacy, \\ Universitas Gadjah Mada, Sekip Utara Yogyakarta 55281 \\ ${ }^{3}$ Laboratory of Macromolecular Engineering, Department of Pharmaceutical Chemistry, Faculty of Pharmacy, \\ Universitas Gadjah Mada, Sekip Utara Yogyakarta 55281
}

\begin{abstract}
Breast cancer is the most common type of cancer causing mortality for women due to metastasis. More than $50 \%$ of breast cancer patients are suffered lung metastases. One strategy to target the cancerous cell is Boron Neutron Captured Therapy (BNCT) which showed high affinity toward cancer cells and reported to have anti-proliferative as well as anti-metastatic activities. Pentagamaboronon-0 (PGB-0) is a curcumin analogue substance which had reported to exert anticancer activities against Her-2 expressing as well as triple negative breast cancer cells. Despite its great potency as BNCT agent candidate, this compound also exerted several anticancer properties. Complex formation of this substance with sorbitol was achieved to improve the solubility and maximize compound's delivery to the target cells. This study aimed to investigate the ability of Pentagamaboronon-0-Sorbitol (PGB-0-So) to modulate cell cycle and induce apoptosis especially through the mechanisms of reactive oxygen species (ROS) modulation. The 3-(4,5-dimethylthiazzol-2yl)-2,5diphenyltetrazolium (MTT) cytotoxicity assay of PGB-0-So against 4T1 breast cancer cell line were found to exert potential effect in dose-dependent manner with lethal concentration $\left(\mathrm{IC}_{50}\right)$ values of $39 \mu \mathrm{M}$. The cytotoxicity of PGB-0-So complex was found to be increased considerably compared with that of PGB-0. Cell cycle modulation identified using propidium iodide (PI) staining showed cell accumulation in S phase following treatment with PGB-0-So. Apoptosis induction assay analyzed using flowcytometer with Annexin $\mathrm{V}$ and PI staining on its $\mathrm{IC}_{50}$ dose was found to induce programmed cell death (apoptosis). The sub-IC $\mathrm{C}_{50}$ treatment of this compound was also improved the cellular ROS level which also took role in apoptosis induction. These findings suggest that PGB-0-So is potential as an anticancer agent.
\end{abstract}

Keywords: Curcumin analogue, PGB-0-So, Anticancer, 4T1 cell line, ROS modulation.

\section{INTRODUCTION}

Breast cancer is the most common type of cancer causing mortality for women which is still poorly identified (Xiao, et al., 2018). In 2012, there were registered 1.67 million new cases of breast cancer mortality in women by 198,000 in all over the world (Ferlay, et al., 2015). It was estimated

Submitted: December 16, 2020

Revised: March 16, 2021

Accepted: March 17, 2021

*Corresponding author: edy_meiyanto@ugm.ac.id 
that $20-25 \%$ of all patients with breast cancer found has Human Epidermal Growth Factor Receptor 2 (HER2) amplification (Mendes, et al., 2015) and approximately $10-15 \%$ of them was known to be triple negative breast cancer (TNBC) (Dawood, 2010). These breast cancer subtypes are positivemetastatic breast cancer (MBC) which have worse prognosis leading to aggressive disease. Metastatic pattern investigation on breast cancer patients showed $57-77 \%$ of them suffered lung metastases (Lee, 1983). Moreover, failure of metastasis prevention primarily caused mortality in breast cancer (Redig and McAllister, 2013).

Curcumin analogues based on benzylidine cyclopentanone backbone such as Pentagamavunon-0(PGV-0) and Pentagamavunon-1 (PGV-1) exerted potent cytotoxic and anti-metastatic activities toward several types of breast cancer cells (Meiyanto, et al., 2014; Putri, et al., 2016). Pentagamaboronon-0 (PGB-0) is a novel curcumin analogue based on benzylidine cyclopentanone developed by Faculty of Pharmacy, Universitas Gadjah Mada. Cytotoxicity of PGB-0 toward HER2 positive breast cancer had been determined and showed to decrease HER2 expression (Utomo, et al., 2017). PGB-0 also performed anti-metastatic activity toward triple negative breast cancer cells (Kusumastuti, et al., 2019). Since this compound showed poor solubility in water, complexation PGB-0 with polyol sugar Sorbitol was done to optimize the potency of this substance as anticancer agent (Chen, et al., 2013; Dash, Srinivas and Babu, 2019). PGB-0-So had reported to inhibit the activity of Matrix Metalloproteinase 9 (MMP-9) which plays role in tumor invasion in several breast cancer cells (Qodria, et al., 2018; Ramadani, et al., 2018).

Reactive oxygen species (ROS) showed an interestingly important role especially in biological processes (Covarrubias, et al., 2008; Abdal Dayem, et al., 2017). Under normal conditions, the regulation of ROS level is conducted steadily to prevent cells from damages through the activation of cell survival signaling cascade involving mitogen-activated protein kinase/extracellular signal-regulated protein kinases 1/2 (MAPK/ERK1/2), p38, c-Jun N-terminal kinase (JNK), and phosphoinositide3-kinase/ protein kinase B (PI3K/Akt) (Simon, et al., 2000; Liou, et al., 2010; Son, et al., 2011; Schattenberg, et al., 2014; Aggarwal, et al., 2019). Moreover, large amount of ROS molecules inside the cell could also trigger oxidative stress which later would regulate cell damage through the mechanisms of cell death induction (He, et al., 2017). Previous researches reported that the elevation of ROS level was detected from many kind of cancers. At high concentrations, ROS can cause cancer cell apoptosis. Therefore, in this study we aim to investigate the potency of Pentagamaboronon-0Sorbitol (PGB-0-So) to induce apoptosis towards triple negative breast cancer cells.

\section{MATERIAL AND METHODS}

\section{Chemicals}

The PGB-0-So complex was prepared according to (Watanabe, et al., 2016) using the PGB-0 and Sorbitol compounds in the ratio $1: 8$. The result of the complexation was in the form of $5 \mathrm{~mL}$ of clear yellow PGB-0-So solution then freeze dry and stored at $4^{\circ} \mathrm{C}$ for further use. The Freeze dried PGB-0-So was dissolved in 5 $\mathrm{mL} \mathrm{ddH2O} \mathrm{and} \mathrm{filtered} \mathrm{using} \mathrm{a} 0.22 \mu \mathrm{m}$ syringe filter. The filter results were then analyzed using a spectrophotometer to determine the concentration of the PGB-0-So compound and the compound could be used for testing.

\section{Cell Culture}

The 4T1 cell line were kindly given by Prof. Dr. Mashashi Kawaichi (NAIST, Japan) and were cultured in $\mathrm{CO}_{2}$ incubator $\left(37^{\circ} \mathrm{C}\right)$ with Dulbecco's Modified Eagle Medium (Gibco, New York, USA) suplemented with 10\% Fetal Bovine Serum (FBS) (Sigma, St. Louis, Missouri, USA), $150 \mu / \mathrm{mL}$ Penicillin and $150 \mu \mathrm{g} / \mathrm{mL}$ Streptomicin (Gibco), and $1.25 \mu \mathrm{g} / \mathrm{mL}$ Fungizone (Amphotericin B) (Sigma). 
Subculture was performed using Trypsin-EDTA (Gibco) for cell detachment. Samples used were synthesized PGB-0-So, as previously described.

\section{3 - (4,5 - dimethylthiazzol-2yl) - 2,5 -} diphenyltetrazolium (MTT) Cytotoxicity Assay

Cytotoxicity assay of was performed using MTT assay adapted from Utomo, et al., 2017. The $2 \times 10^{3}$ of $4 \mathrm{~T} 1$ cells were seeded into each well on 96 well-plate. On the next day, cells were treated with PGB-0-So by the series of concentrations $(5,10,15$, $25,50,75$, and $100 \mu \mathrm{M}$ ) for $24 \mathrm{~h}$. Cells were added with $100 \mathrm{uL}$ of $0.5 \mathrm{mg} / \mathrm{mL}$ MTT reagent (Biovision, California, USA) and incubated for 2-4 h. At the end of incubation period, SDS stopper solution containing $0,01 \mathrm{~N} \mathrm{HCl}$ was added to each well. The absorbance was measured by ELISA reader at $\lambda 595 \mathrm{~nm}$. Cells were added with $100 \mathrm{uL}$ of 0.5 $\mathrm{mg} / \mathrm{mL}$ MTT reagent and incubated for 2-4 h. At the end of incubation period, SDS stopper solution containing $0,01 \mathrm{~N} \mathrm{HCl}$ was added to each well. The absorbance was measured by ELISA reader at $\lambda 595$ $\mathrm{nm}$. In combination cytotoxic assay, combination index value was examined using CompuSyn ${ }^{\circledR}$ software and the category was defined based on Patrick Reynolds and Maurer (2005). The potential application in combination therapy was analyzed using the combinatorial index method (CI) based on Reynold and Maurer (2005).

\section{Cell Cycle Assay}

Cell cycle assay of this research was performed using flowcytometer according to Amalina, et al., 2017. A total of $2 \times 10^{5}$ cells $/ \mathrm{mL}$ of 4T1 cells were seeded in each well of 6-well plate with DMEM medium (10\% FBS, $1.5 \%$ penicillinstreptomycin, $0.5 \%$ fungizone) and incubated in an incubator $\left(5 \% \mathrm{CO}_{2}, 37^{\circ} \mathrm{C}\right)$ for $24 \mathrm{~h}$. Furthermore, cells were treated with PGB-0-So compound at concentrations of 40 and $60 \mu \mathrm{M}$ for $24 \mathrm{~h}$. On the next day, cell harvesting and centrifugation were carried out to obtain cell pellets. Cells were fixed with $70 \%$ ethanol for 30 minutes and stained with propidium iodide (PI) (400 $\mu$ PI reagent containing
$1 \mathrm{mg} / \mathrm{mL}$ PI, $10 \mathrm{mg} / \mathrm{mL}$ RNAse and $0.1 \%(\mathrm{v} / \mathrm{v})$ Triton-X 100) to read after 30 minutes using the FACS Calibur flowsitometer.

\section{Apoptosis Assay}

Apoptosis assay was conducted by Annexin V-FITC/PI staining flowcytometry according to Putri, et al., 2016. The $2 \times 10^{5} 4 \mathrm{~T} 1$ cells were seeded in each well of 6-well plate and treated with the different concentrations of PGB-0-So for $24 \mathrm{~h}$. Cells were harvested using trypsin-EDTA, collected, and stained Annexin-V-FLUOS staining kit (Roche, Zhangjian Hi-Tech Park, Shanghai, China) consisting of $500 \mathrm{~mL}$ of binding buffer, $2 \mathrm{~mL}$ of Anexin V and PI and incubated for 10 minutes in the dark room, according to manufacturer's instruction, then the cells were analyzed with flowcytometer (FACS Calibur).

\section{Reactive Oxygen Species (ROS) Assay}

The $4 \mathrm{~T} 1$ cells in as much as $5 \times 10^{4}$ were seeded into each well of 24-well plates. Incubation cells for $24 \mathrm{~h}$ at an incubator temperature of $37^{\circ} \mathrm{C}$. Then, the cells were harvested in $500 \mu \mathrm{L}$ supplemented buffer (10\% FBS in 1x PBS). Furthermore, cell staining was conducted by adding $15 \mu \mathrm{M}$ Dichlorodihydrofluorescein diacetate (DCFDA) (3.75 $\mu \mathrm{L} 2 \mathrm{mM}$ DCFDA) (Abcam, Cambridge, UK) and incubated for 30 minutes in an incubator. The experiments was conducted as its describe on manufacturer's instruction. 4T1 cells were treated with concentrations of 40 and $60 \mu \mathrm{M}$ of PGB-0-So compounds and treatment with $1 \mu \mathrm{M}$ $\mathrm{H}_{2} \mathrm{O}_{2}$ as a positive control group. Incubation at $37^{\circ} \mathrm{C}$ for 3-4 $\mathrm{h}$ and analyzed by using a flowcytometer (FACS Calibur).

\section{RESULT}

\section{Cytotoxicity of Pentagamaboronon-0- Sorbitol (PGB-0-So)}

Single cytotoxic assay of PGB-0-So compound showed a dose-dependent inhibitory profile in $4 \mathrm{~T} 1$ breast cancer cells (Figure 1). The 
A

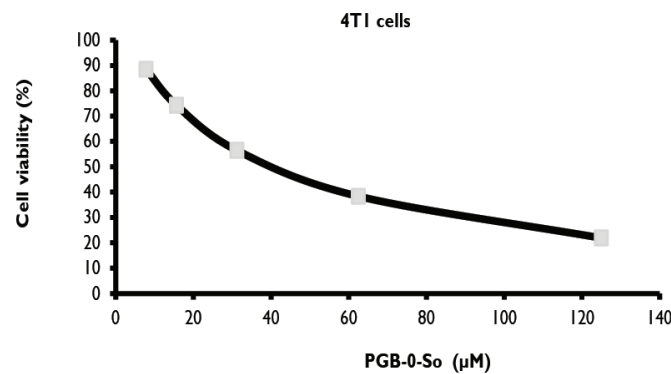

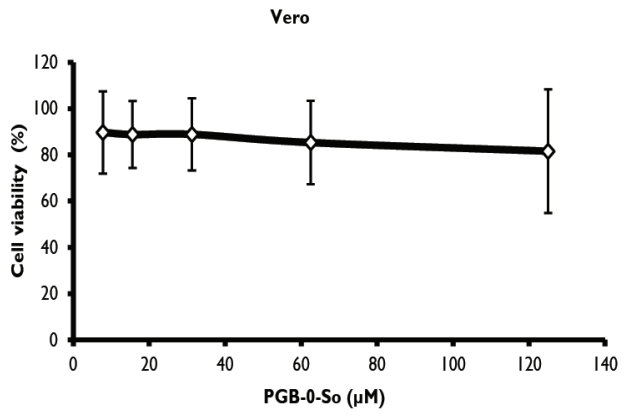

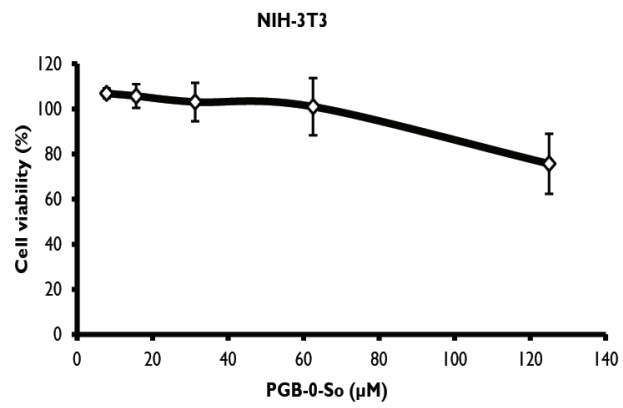

Figure 1. The Cytotoxicity Profile of PGB-0-So on Several Cell Lines. (A) The single cytotoxicity profile of PGB-0-So and conjugated sugar Sorbitol against 4T1 cell, (B) The single cytotoxicity profile of PGB-0-So against normal cell model Vero, $(C)$ The single cytotoxicity profile of against normal cell model NIH-3T3. Cells were treated with several concentration of PGB-0-So and Sorbitol (A) for $24 \mathrm{~h}$ then was analyzed by MTT assay. After regression analysis, the $\mathrm{IC}_{50}$ was measured by excel software $(P<0.01)$. All data were conducted on three independent experiment $(n=3)$. The single cytotoxicity test of PGB-0-So against triple negative breast cancer cell 4T1 cell showed the decrease of cell viability in dose-dependent manner, while the single cytotoxicity test of the conjugated sugar Sorbitol showed no toxic effect of Sorbitol agaist triple negative breast cancer cell 4T1 cell. PGB-0-So was also found non-toxic into two normal cell models, Vero and $\mathrm{NIH}-3 \mathrm{~T} 3$ cell line.

graph above shows that the higher the concentration of the PGB-0-So compound given, the lower the viability of $4 \mathrm{~T} 1$ breast cancer cells based on linear regression line interpolation. These data indicate that the PGB-0-So compound is toxic to 4T1 cells with a lethal concentration $\left(\mathrm{IC}_{50}\right)$ of $40 \mu \mathrm{M}$. Moreover, the $\mathrm{IC}_{50}$ value of PGB-0-So on Vero and NIH-3T3 were $>250$ and $>150$, respectively. According to the selectivity index, PGB-0-So is considered as selective toward cancer cells based on $\mathrm{SI}>3$, in which $>6$ in Vero, and $>3$ in NIH-3T3 cells.

Combination treatment of $1 / 2 \mathrm{IC}_{50}$ PGB-0-So compound and $1 / 2 \mathrm{IC}_{50}$ doxorubicin compound was able to reduce cell viability by up to $70 \%$ compared to the control group (Figure 2). Combination of
PGB-0-So with doxorubicin showed the synergistic effect of the PGB-0-So and doxorubicin causing the accumulation of cytotoxic effects between the two tested compounds compared with a single treatment.

\section{Effect of Pentagamaboronon-0-Sorbitol (PGB-0-So) in 4T1 Cell Cycle Modulation}

The treatment of PGB-0-So compounds on $4 \mathrm{~T} 1$ breast cancer cells for $24 \mathrm{~h}$ is known to be able to modulate the cell cycle and cause accumulation in the $\mathrm{S}$ phase of the cell cycle (Figure 3 ). The administration of PGB-0-So at concentrations of $40 \mu \mathrm{M}$ and $60 \mu \mathrm{M}$ showed an increase in cell accumulation in the $\mathrm{S}$ phase along with the increasing dose of PGB-0-So treatment given. 
A

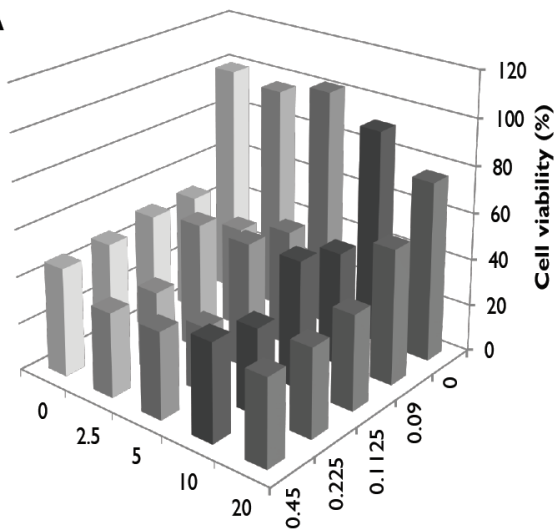

\begin{tabular}{|c|cccc|}
\hline \multicolumn{5}{|c|}{ Combination Index } \\
\hline $\begin{array}{c}\text { PGB-0-So } \\
(\mu \mathrm{M})\end{array}$ & 0.09 & 0.1125 & 0.225 & 0.45 \\
\cline { 2 - 5 } & \multicolumn{5}{|c|}{ Dox } \\
\hline 2.5 & 0.06 & 0.08 & 0.06 & 0.08 \\
5 & 0.14 & 0.15 & 0.1 & 0.13 \\
10 & 0.25 & 0.29 & 0.22 & 0.25 \\
20 & 0.6 & 0.44 & 0.43 & 0.44 \\
\hline
\end{tabular}

Figure 2. The cytotoxic effect of PGB-0-So in combination with Doxorubicin on TNBC 4T1 Cells. A. Cytotoxic profile of PGB-0-So in combination with Doxorubicin on 4T1 describing correlation between concentration and cell viability. B. Table of Combination Index of PGB-0-So with Doxorubicin on 4T1 cells. PGB-0-So performed synergic effect with Doxorubicin with combination index $<1$ against $4 \mathrm{~T} 1$ cells.

Treatment with $40 \mu \mathrm{M}$ PGB-0-So increased the S phase up to $11.92 \%$, meanwhile treatment with $60 \mu \mathrm{M}$ PGB-0-So increased the S phase by up to $12.59 \%$, both compared to control cells without treatment with PGB-0-So.

\section{Effect of Pentagamaboronon-0-Sorbitol (PGB-0-So) in Apoptosis Induction}

A single cytotoxic test of PGB-0-So compound showed the occurrence of cell death after incubation for $24 \mathrm{~h}$, then it is necessary to confirm which of the cell death pathway influenced by the compound. In this study, further apoptosis induction experiment was carried out using a flowcytometer. The data showed an increase in the induction of early stage and late stage apoptosis along with PGB-0-So treatment by the concentrations of 40 $\mu \mathrm{M}$ and $60 \mu \mathrm{M}$ (Figure 3). Treatment with PGB0 -So compounds generally induced an increase in 4T1 breast cancer cell death. The cell control group had a necrosis mortality rate of $1.4 \%$, an early phase of apoptosis of $3 \%$ and a late phase of apoptosis of $1.54 \%$. In the group treated with $40 \mu \mathrm{M}$ of PGB-0So compound, the percentage of necrosis mortality was detected $0.77 \%$; the early phase of apoptosis was $7.18 \%$ and the final phase of apoptosis was
$7 \%$. Meanwhile, in the group treated with $60 \mu \mathrm{M}$ of PGB-0-So compound, the percentage of necrosis mortality was detected $0.71 \%$; the initial phase of apoptosis was $9.41 \%$ and the final phase of apoptosis was $9.41 \%$.

\section{Reactive Oxidative Stress (ROS) Generation upon Pentagamaboronon-0-Sorbitol (PGB-0- So) Treatment}

The cytotoxicity and anti-proliferative activities of the PGB-0-So compound against 4T1 breast cancer cells can occur due to increased levels of ROS (Liou and Storz, 2010; Aggarwal, et al., 2019). In this study, the ROS intercellular level test was carried out using fluorescent compounds and cell permeable chemiluminescent probes, namely DCFDA which were then measured using flowcytometry. Based on the results below, it can be seen that incubation with the PGB-0-So compound on 4T1 breast cancer cells for $4 \mathrm{~h}$ was able to increase the ROS level, the higher the PGB-0-So treatment given the higher the ROS level detected. The treatment group with $40 \mu \mathrm{M}$ and $60 \mu \mathrm{M}$ PGB0 -So compound showed DCFDA mean fluorescence of 1.25 and 1.45 which was higher than the positive control group with $\mathrm{H}_{2} \mathrm{O}_{2}$. This result showed the 
role of PGB-0-So as a pro-oxidant that might able to increase cellular ROS level. Increasing the ROS level beyond the threshold can induce death in cancer cells (Atsumi, et al., 2007; Larasati, et al., 2018) .

\section{DISCUSSION}

This study aims to study one of the curcumin analogue compounds, namely PGB-0 which is reacted with PGB-0-So as a chemotherapy agent in triple negative $4 \mathrm{~T} 1$ breast cancer cells. The initial screening to determine the potential of PGB0 -So compounds in inhibiting the proliferative activity of highly metastatic 4T1 breast cancer cells was a cell cytotoxicity test using the MTT Assay chlorometric method. Single cytotoxic test of PGB0-So compound against 4T1 breast cancer cells showed a decrease in cell viability in accordance with the dose (dose-dependent manner) with an $\mathrm{IC}_{50}$ value of $40 \mu \mathrm{M}$. Meanwhile, sorbitol, which in this study was reacted with the PGB-0 compound to increase the solubility of the compound, did not show cytotoxicity effects on 4T1 breast cancer cells. It showed that the cytotoxic potential exerted by PGB-0-So compound is not an accumulation of cytotoxic effects between the two compounds being reacted. Based on the results of testing the cytotoxicity activity of PGB-0-So, compound's complexation with sorbitol not only improved its solubility but also its cytotoxic properties compared to previous studies. Utomo, et al., 2017 reported that PGB-0 inhibited MCF-7/HER2 cell growth with the $\mathrm{IC}_{50}$ value of $270 \mu \mathrm{M}$ while Kusumastuti, et al., 2019 reported that PGB-0 showed cytotoxic effect against 4T1 cell with the $\mathrm{IC}_{50}$ value of $294 \mu \mathrm{M}$. This result explained that complexation with sorbitol significantly increased PGB-0 cytotoxicity against breast cancer cells. Nevertheless further research is needed regarding the stability and solubility of this compounds. In addition, in the development of PGB-0-So as BNCT agents, further testing regarding the transportation and accumulation of the compound in cells are importantly needed.

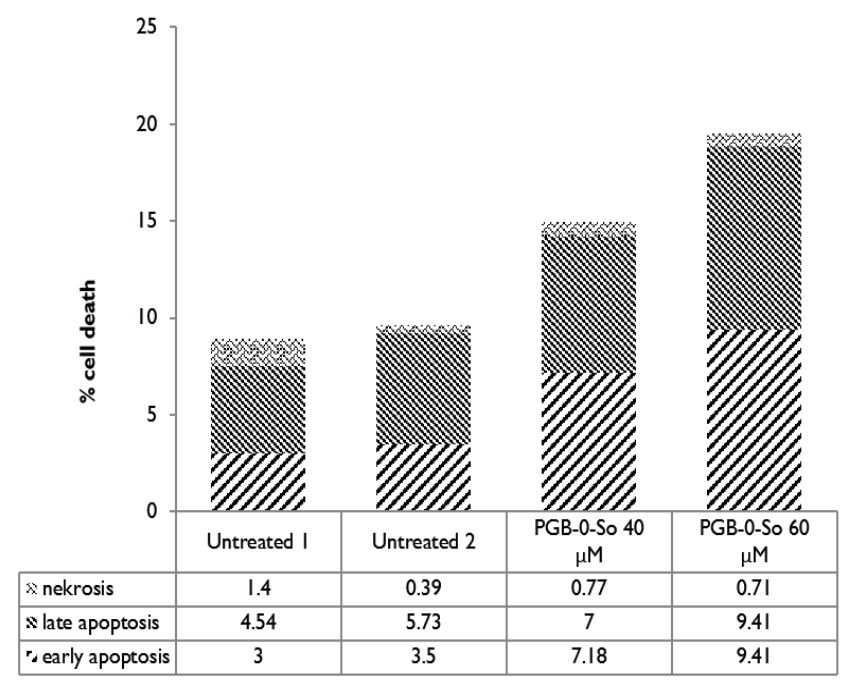

Figure 3. The Effect of PGB-0-So on Cell Cycle Modulation and Apoptosis Induction against TNBC 4T1 cell. Cells were treated with $40 \mu \mathrm{M}$ and $60 \mu \mathrm{M}$ of PGB-0-So against $4 \mathrm{~T} 1$ cells for $24 \mathrm{~h}$. The cells then harvested and conducted DNA content analysis by flow cytometry with PI staining for cell cycle modulation analysis and with Annexin-V and PI for apoptosis induction analysis. Cell cycle profiles in the sub-G1, G1, S, and $\mathrm{G} 2 / \mathrm{M}$ of the cells and the quantification of cell distribution on the each cell cycle phase. PGB-0-So revealed S phase arrest as well as apoptosis induction at the concentration $40 \mu \mathrm{M}$. 
Cytotoxic testing of the combination of PGB-0-So compounds with doxorubicin showed a synergistic effect of the two compounds on 4T1 breast cancer cells. Previous studies reported that at certain concentrations, the combination of curcumin and the chemotherapy agent doxorubicin has a synergistic effect and is able to influence down regulation of the expression of several genes including: c-myc, Bcl-XL, c-IAP-2, NAIP, XIAP which play an important role in maintaining the ability to proliferate cancer cells (Notarbartolo, et al., 2005; Limtrakul, 2007). In this study, the sublethal dose of PGB-0-So and doxorubicin were found to be able to reduce the viability of $4 \mathrm{~T} 1$ breast cancer cells by up to $70 \%$, this is in line with previous studies which stated that the synergistic effect of the combination of curcumin analogue compounds with doxorubicin was obtained at sub $\mathrm{IC}_{50}$ doses (Putri, et al., 2016; Kusumastuti, et al., 2019). It indicates that PGB-0-So can be combined with doxorubicin as a co-chemotherapy compound with a smaller chemotherapy dose.

The findings of the compound cytotoxicity test then can be confirmed through the cell cycle modulation test using the flowcytometry method. The single treatment of the PGB-0-So compound is able to modulate the cell cycle through induction arrest in the synthesis phase (S phase) of the cell cycle. They are in line with previous research which shows that the DBBAC or PGB-0 compound causes S-phase arrest which is most likely due to DNA damage (Kusumastuti, et al., 2019). DNA damage results in the accumulation of broken DNA double strands which is induced by topoisomerase I inhibitor (SN38), this event has implications for arrest in the $\mathrm{S}$ phase of the cell cycle. Cancer cells that did not undergo arrest in the G1 phase after treatment with flavopiridol showed growth inhibition activity in the S phase which could then experience cell death (apoptosis) earlier and more efficient than cells that undergo arrest in the G1 phase after treatment with drug compounds. Failure of G1 arrest due to the presence of Cyclin dependent kinase (Cdk) inhibitors increases the apoptotic response of cells (Doumont, et al., 2005). A further test to confirm the results of cytotoxic tests and the results of cell cycle modulation tests was apoptosis induction test. In apoptosis testing with flowcytometry, we need to identify membrane conditions and cell genetic material $24 \mathrm{~h}$ after treatment. The initial phase of apoptosis is characterized by translocation of phosphatidylserine (PS) on the inner cell membrane to the outer membrane. This displacement causes PS to face the outside of the cell so that it is able to

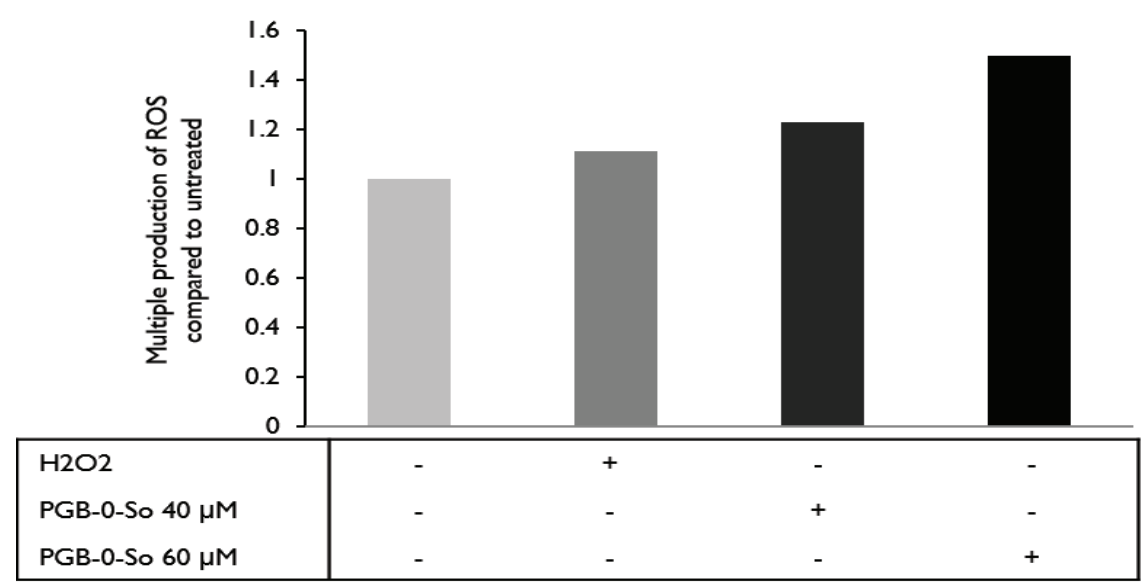

Figure 4. PGB-0-So modulated the ROS level of TNBC 4T1 Cells. Cells were stained with DCFDA then treated with two different concentrations PGB-0-So for $4 \mathrm{~h}$ and then subjected to FACS flowcytometry. X-axis, the cellular ROS level; Y-axis, the relative cell count. ROS level elevated after treatment with PGB-0-So in dose-dependent manner. 
interact with the external proteins of the cell. In this test, detection of the presence of PS was carried out using Annexin V (in the form of $\mathrm{Ca} 2+$-dependent phospholipid-binding protein) which is a specific protein and is able to strongly interact with the PS residue. The detection of PS in cells indicates an early phase of cell death in the apoptotic pathway (Elmore, 2007). The detection of apoptotic events is also carried out with PI which is able to intercalate with DNA so that it can show the DNA content of cells. The final phase of apoptosis is characterized by the occurrence of DNA fragmentation followed by loss of nuclear DNA, which can be detected using a PI. Viable cells will have low Annexin V and PI intensities (Vermes, et al., 1995; Riccardi and Nicoletti, 2006).

Incubation with PGB-0-So compound showed the ability of the compound to induce an increase in the percentage of cell death in the apoptotic pathway. The mechanism of apoptosis induction in $4 \mathrm{~T} 1$ breast cancer cells is most likely to occur via the p53-independent mitochondrial pathway (intrinsic pathway). This is because triple negative breast cancer cells, such as 4T1 cells used in this study, have mutations in the $\mathrm{p} 53$ protein which play an important role in the induction of apoptosis in the extrinsic pathway (Yerlikaya, et al., 2012). Incubation with the PGB-0-So compound is possibly affected depolarization of the mitochondrial membrane so that cytochrome $\mathrm{C}$ is released from the membrane, cytochrome $\mathrm{C}$ then activates caspase 9 which can induce activation of other caspases (caspase 3). Activation of caspase protein then induces activation of endonuclease and proteases which play a role in the degradation of chromosomal DNA, nuclear lamina and cytoskeletal proteins until apoptosis occurs (Tsang, et al., 2003; Elmore, 2007; Karp, 2008).

To understand more deeply about the cytotoxic and anti-proliferative effects of PGB-0So compounds on 4T1 breast cancer cells, as well as the mechanisms for inducing cell death that are likely to occur, in this study, intracellular ROS levels were tested in 4T1 breast cancer cells after incubation with compound PGB-0-So for about $4 \mathrm{~h}$. In this study, it can be seen that there was an increase in ROS levels in cells incubated with the PGB-0-So compound compared to the untreated control group (as a negative control group) and the group induced by addition of $\mathrm{H}_{2} \mathrm{O}_{2}$ (as a positive control group). ROS can be in the form of ions or radical molecules with one single electron in the outer layer of the electron layer, so it has a very high reactivity. In normal conditions, ROS is very tightly guarded by the presence of antioxidants and repair mechanisms so that it does not cause oxidative stress (Manda, et al., 2009). Elevated levels of ROS beyond the normal threshold are known to cause cancer cell death. Previous studies reported that curcumin has the ability as a pro-oxidant agent capable of inducing increased production of ROS in cells (Atsumi, Tonosaki and Fujisawa, 2007; Larasati, et al., 2018). In cells ROS acts as a messanger in the signal transduction pathway, influences protein phosphatase and plays an important role in the regulation of transcription factors (Chiarugi, et al., 2003; Torres, et al., 2003; Zhang, et al., 2004). ROS can affect the activation of several important genes for transcription factors, including the c-fos, c-jun, ATF, JDP and NF-кB gene families (Manda, et al., 2009). In addition, high production of ROS can induce apoptosis by influencing the expression and translocation of Bax to mitochondria, causing mitochondrial damage, release of cytochrome c, activation of caspase 3 resulting in apoptosis (Dumay, et al., 2006; Susnowa, et al., 2009; RedzaDutordoir, et al., 2016).

\section{CONCLUSION}

The PGB-So treatment against TNBC cell 4T1 was able to modulate cell cycle and induce apoptosis especially through the elevation of the cellular ROS level. These findings suggest that PGB-0-So is potential as an anticancer agent. 


\section{ACKNOWLEDGEMENTS}

This Research is supported by grants from Penelitian Dasar Unggulan Perguruan Tinggi (PDUPT) 2020 contract No. 1668/UN1/ DITLIT/DIT-LIT/PT/2020, Indonesian Ministry of Research, Technology and Higher Education.

\section{REFERENCES}

Aggarwal, V., Tuli, H.S., Varol, A., Thakral, F. Yerer, M.B., Sak, K., et al., 2019, Role of Reactive Oxygen Species in Cancer Progression: Molecular Mechanisms and Recent Advancements, Biomolecules, 9(11), 735.

Amalina, N.D., Nurhayati, I.P. and Meiyanto, E., 2017, Doxorubicin Induces Lamellipodia Formation and Cell Migration, Indonesian Journal of Cancer Chemoprevention, 8(2), 61-67.

Atsumi, T., Tonosaki, K. and Fujisawa, S., 2007, Comparative cytotoxicity and ROS generation by curcumin and tetrahydrocurcumin following visible-light irradiation or treatment with horseradish peroxidase, Anticancer Research, 27(1A), 363-371.

Chen, M.-L., Sadrieh, N. and Yu, L., 2013, Impact of Osmotically Active Excipients on Bioavailability and Bioequivalence of BCS Class III Drugs, The AAPS Journal, 15(4), 1043-1050.

Chiarugi, P. and Cirri, P., 2003, Redox regulation of protein tyrosine phosphatases during receptor tyrosine kinase signal transduction, Trends in Biochemical Sciences, 28(9), 509-514.

Covarrubias, L., Hernandez-Garcia, D., Schnabel, D. and Salas-Vidal, E., 2008, Function of reactive oxygen species during animal development: Passive or active?, Developmental Biology, 320(1), 1-11.

Dash, R.P., Srinivas, N.R. and Babu, R.J., 2019, Use of sorbitol as pharmaceutical excipient in the present day formulations-issues and challenges for drug absorption and bioavailability, Drug Development and Industrial Pharmacy, 45(9),
1421-1429.

Dawood, S., 2010, Triple-negative breast cancer: epidemiology and management options, Drugs, 70(17), 2247-2258.

Dayem, A.A., Hossain, M.K., Lee, S.B., Kim, K., Saha, S., Yang, G-M., et al., 2017, The Role of Reactive Oxygen Species (ROS) in the Biological Activities of Metallic Nanoparticles, International Journal of Molecular Sciences, 18(1), 120.

Doumont, G., Martoriati, A., Beekman, C., Bogaerts, S., Mee, P. J., Bureau, F., Colombo, E., Alcalay, M., Bellefroid, E., Marchesi, F., Scanziani, E., Pelicci, P. G., and Marine, J., 2005, G1 checkpoint failure and increased tumor susceptibility in mice lacking the novel p53 target Ptprv, The EMBO Journal, 24(17), 3093-3103.

Dumay, A., Rincheval, V., Trotot, P., Mignotte, B. and Vayssière, J., 2006, The superoxide dismutase inhibitor diethyldithiocarbamate has antagonistic effects on apoptosis by triggering both cytochrome $c$ release and caspase inhibition, Free Radical Biology \& Medicine, 40(8) 1377-1390.

Elmore, S., 2007, Apoptosis: A Review of Programmed Cell Death, Toxicologic pathology, 35(4), 495516.

Ferlay, J., Soerjomataram, I., Dikshit, R., Eser, S., Mathers, C., Rebelo, M., et al., 2015, Cancer incidence and mortality worldwide: Sources, methodsand major patterns in GLOBOCAN 2012, International Journal of Cancer, 136(5), 359386.

He, L., He, T., Farrar, S., Ji, L., Liu, T. and Ma, X., 2017, Antioxidants Maintain Cellular Redox Homeostasis by Elimination of Reactive Oxygen Species, Cellular Physiology and Biochemistry, 44(2), 532-553.

Karp, G., 2008, Cell and Molecular Biology : concept and experiment, in. John-Willey and Sons Inc. Hoboken., p. 654.

Kusumastuti, R., Utomo, R.Y., Khumaira, A., Putri, H., Jenie, R.I. and Meiyanto, E., 2019, Pentagamaboronon-0 increased cytotoxicity 
of and inhibited metastasis induction by doxorubicin in breast cancer cells, Journal of Applied Pharmaceutical Science, 9(06), 43-51.

Larasati, Y.A., Yoneda-Kato, N., Nakamae, I., Yokoyama, T., Meiyanto, E. and Kato, J-y., 2018, Curcumin targets multiple enzymes involved in the ROS metabolic pathway to suppress tumor cell growth, Scientific Reports, 8, 2039.

Lee, Y.T., 1983, Breast carcinoma: pattern of metastasis at autopsy, J. Surg. Oncol., 3(23), 175-180.

Limtrakul, P. , 2007, Curcumin as Chemosentizer, in Aggarwal, B.B., Surh, Y.-J., and Shishodia, S. (eds) The Molecular Targets and Therapeutic Uses of Curcumin in Health and Disease. Boston, MA: Springer US (Advances in Experimental Medicine and Biology), 269-300.

Liou, G.-Y. and Storz, P., 2010, Reactive oxygen species in cancer, Free radical research, 44(5), 479-496.

Nechifor, M.T., Neagu, T-M. and Manda, G., 2009, Reactive Oxygen Species, Cancer and AntiCancer Therapies, Current Chemical Biology, 3(1), 22-46.

Meiyanto, E., Putri. D.D.P., Susidarti, R.A., Murwanti, R., Sardjiman, Fitriasari, A., et al., 2014, Curcumin and its Analogues (PGV-0 and PGV-1) Enhance Sensitivity of Resistant MCF-7 Cells to Doxorubicin through Inhibition of HER2 and NFkB Activation, Asian Pacific Journal of Cancer Prevention, 15(1), 179-184.

Mendes, D., Alves, C., Afonso, N., Cardoso, F., PassosCoelho, J.L., Costa, L., et al., 2015, The benefit of HER2-targeted therapies on overall survival of patients with metastatic HER2-positive breast cancer - a systematic review, Breast Cancer Research, 17(1), 140.

Mosmann, T., 1983, Rapid colorimetric assay for cellular growth and survival: application to proliferation and cytotoxicity assays, Journal of Immunological Methods, 65(1-2), 55-63.

Notarbartolo, M., Poma, P., Perri, D., Dusonchet, L., Cervello, M., D’Alessandro, N., 2005, Antitumor effects of curcumin, alone or in combination with cisplatin or doxorubicin, on human hepatic cancer cells. Analysis of their possible relationship to changes in NF-kB activation levels and in IAP gene expression, Cancer Letters, 224(1), 53-65.

Putri, H., Jenie, R.I., Handayani, S., Kastian, R.F. and Meiyanto, E., 2016, Combination of Potassium Pentagamavunon-0 and Doxorubicin Induces Apoptosis and Cell Cycle Arrest and Inhibits Metastasis in Breast Cancer Cells, Asian Pacific journal of cancer prevention, 17(5), 2683-2688.

Qodria, L., Hairunisa, I., Utomo, R.Y., Hermawan, A. and Meiyanto, E., 2018, Anti-metastatic Activity of Curcumin Analog Pentagamaboronon-0Sorbitol Against HER2-overexpressed MCF-7 Breast Cancer Cells, Indonesian Journal of Cancer Chemoprevention, 9(3), 118-125.

Ramadani, R.D., Utomo, R.Y., Hermawan, A. and Meiyanto, E., 2018, Curcumin Analog Pentagamaboronon-0-Sorbitol Inhibits Cell Migration Activity of Triple Negative Breast Cancer Cell Line, Indonesian Journal of Cancer Chemoprevention, 9(3), 126-133.

Redig, A.J. and McAllister, S.S., 2013, Breast cancer as a systemic disease: a view of metastasis, Journal of internal medicine, 274(2), 113-126.

Redza-Dutordoir, M. and Averill-Bates, D.A., 2016, Activation of apoptosis signalling pathways by reactive oxygen species, Biochimica et Biophysica Acta, 1863(12), 2977- 2992.

Reynolds, C.P. and Maurer, B.J., 2005, Evaluating response to antineoplastic drug combinations in tissue culture models, Methods Mol Med, 110, 173- 183.

Riccardi, C. and Nicoletti, I., 2006, Analysis of apoptosis by propidium iodide staining and flow cytometry, Nature Protocols, 1(3), 1458-1461.

Schattenberg, J.M. and Czaja, M. J., 2014, Regulation of the effects of CYP2E1-induced oxidative stress by JNK signaling, Redox Biology, 3, 7-15.

Simon, H.-U., Haj-Yehia, A. and Levi-Schaffer, F., 2000 , Role of reactive oxygen species (ROS) in 
apoptosis induction, Apoptosis, 5(5), 415-418.

Son, Y., Cheong, Y-K., Kim, N-H., Chung, H-T., Kang, D.G. and Pae, H-O., 2011, Mitogen-Activated Protein Kinases and Reactive Oxygen Species: How Can ROS Activate MAPK Pathways?, Journal of Signal Transduction, 2011, 792639.

Susnow, N., Zheng, L., Margineantu, D., and Hockenbery, D.M., 2009. Bcl-2 family proteins as regulators of oxidative stress, Semin Cancer Biol., 19(1): 42-49.

Torres, M. and Forman, H.J., 2003, Redox signaling and the MAP kinase pathways, BioFactors, 17(14), 287-296.

Tsang, W.P., Chau, S.P.Y., Kong, S.K., Fung, K.P. and Kwok, T.T., 2003, Reactive oxygen species mediate doxorubicin induced p53-independent apoptosis, Life Sciences, 73(16), 2047-2058.

Utomo, R.Y., Putri, H., Pudjono, Susidarti, R.A., Jenie, R.I. and Meiyanto, E., 2017, Synthesis and Cytotoxic Activity of 2,5-BIS(4-Boronic Acid)Benzylidine Cyclopentanone on HER2 Overexpressed-Cancer Cells, Indonesian Journal of Pharmacy, 28(2), 74-81.

Vermes, I., Haanen, C., Steffens-Nakken, H. and Reutelingsperger, C., 1995, A novel assay for apoptosis Flow cytometric detection of phosphatidylserine expression on early apoptotic cells using fluorescein labelled Annexin V, Journal of Immunological Methods, 184(1), 39-51.

Watanabe, T., Hattori, Y., Ohta, Y., Ishimura, M., Nakagawa, Y., Sanada, Y., et al., 2016, Comparison of the pharmacokinetics between L-BPA and L-FBPA using the same administration dose and protocol: a validation study for the theranostic approach using [18F]-L-FBPA positron emission tomography in boron neutron capture therapy, BMC cancer, 16(1), 859.

Xiao, W., Zheng, S., Liu, P., Zou, Y., Xie, X., Yu, P., et al., 2018, Risk factors and survival outcomes in patients with breast cancer and lung metastasis: a population- based study, Cancer Medicine, 3(7), 922-930.

Yerlikaya, A., Okur, E. and Ulukaya, E., 2012, The p53-independent induction of apoptosis in breast cancer cells in response to proteasome inhibitor bortezomib, Tumour Biology, 33(5), 1385-1392.

Zhang, Y. and Chen, F., 2004, Reactive oxygen species (ROS), troublemakers between nuclear factorkappaB (NF-kappaB) and c-Jun $\mathrm{NH}(2)$-terminal kinase (JNK), Cancer Research, 64(6), 19021905. 


\title{
Bone Resorption in Ameloblastoma and Its Underlying Mechanism
}

\author{
Jackson $^{1}$, Johni Halim ${ }^{1}$, Rezky Anggraeni ${ }^{1}$, Ferry Sandra ${ }^{2 *}$ \\ ${ }^{1}$ Postgraduate Program in Dentistry, Faculty of Dentistry, Universitas Trisakti, Jakarta, Indonesia \\ ${ }^{2}$ Department of Biochemistry and Molecular Biology, Division of Oral Biology, Faculty of Dentistry, Universitas Trisakti, \\ Jakarta, Indonesia
}

\begin{abstract}
Ameloblastoma, a tumor located in the jaw, grows slowly but locally invasive. Ameloblastoma expands in the jaw based on a mechanism resorbing the surrounding bone. To date, the bone resorption mechanisms of ameloblastoma are associated with the expression of receptor activator of nuclear factor (NF)-KB (RANK) ligand (RANKL), matrix metalloproteinases (MMPs), and tumor necrosis factor (TNF)-a. RANKL plays an important role in generating osteoclastogenesis. MMPs degrade the extracellular matrix. TNF- $a$ can induce the formation of osteoclast and modulate the MMPs. In this review the bone resorption mechanism of ameloblastoma as well its signaling pathway will be disclosed.
\end{abstract}

Keywords: Ameloblastoma, RANKL, MMPs, TNF-a.

\section{INTRODUCTION}

One of the most common benign epithelial odontogenic tumors of the jaw is ameloblastoma. Ameloblastoma has the characteristics of slow growth and locally invasive. The peak incidence of ameloblastoma is in the third and fourth decades of life, but ameloblastoma can occur at all ages, equal in gender distribution. In Caucasians, most ameloblastomas occur in the molar-ramus region, with over $50 \%$ prevalence. Most ameloblastomas occur in the mandibular symphysis in the Asian Indian and Nigerian population (Petrovic, et al., 2018). Ameloblastoma usually occurs in a unilateral form (95\%). Overall, ameloblastomas arise mostly in the mandible (80-93\%) (Singh, et al., 2015). In Indonesia, multicystic follicular ameloblastoma was the most common type (57\%), followed by unicystic (25\%) and unspecified multicystic (18\%) (Ruslin, et al., 2018). In Southeast Myanmar and Lower Northern Thailand, ameloblastoma was shown multilocular radiolucency in $70 \%$ cases and unilocular radiolucency in 30\% cases. Unicystic ameloblastoma (20\%), conventional solid/multicystic ameloblastoma (70\%), and desmoplastic ameloblastoma (10\%) were diagnosed in Lower Northern Thailand, Southeast Myanmar, and Thailand regions. The most common histologic pattern was the plexiform type (57.2\%), followed by the follicular type (23.8\%) (Intapa, 2017).

A 40-year epidemiologic study in Iran showed the most frequent location of the tumor was the mandibles (93.2\%) (Saghravanian, et al., 2016). Ameloblastoma is mainly located in the third molar region; $20 \%$ of ameloblastoma arises in the

Submitted: January 12, 2021

Revised: February 23, 2021

Accepted: February 25, 2021

*Corresponding author: ferry@trisakti.ac.id 
maxilla, particularly in the posterior region. Desmoplastic ameloblastoma, a rare subtype ( $2 \%$ of all ameloblastomas), arises most frequently in the premolar and anterior regions of the mandible and the maxilla (Kreppel and Zoller, 2018). As the development of odontogenic tumors was associated with remnants of the migrating epithelium at the cervical loop of the enamel organ, it was not surprising that the development of ameloblastoma was also linked to the enamel organ remnants of odontogenic epithelium and lining of odontogenic cyst. This odontogenic etiological origin was further supported by the similarities in the expression profiles of cytokeratin and vimentin between the developing tooth germ and ameloblastoma (Effiom, et al., 2018). The molecular pathogenesis of ameloblastoma is now attributed to dysregulation of the mitogen-activated protein kinase (MAPK) pathway based on studies using ameloblastoma tissues, cell lines, and transgenic mice (Brown, et al., 2015).

Various risk factors have been associated and studied which might be involved in triggering development and progression of ameloblastoma such as chronic inflammatory responses, viral infection (human papillomavirus), malnutrition, deficiency of either vitamins/proteins/minerals, improper dental health, individual's genetic polymorphism (Toprani, 2020), chemical exposure (arsenic, lead, drugs, occupational-related exposures), radiation, and pollution (air, water, and foodborne) (Sun, et al., 2020).

Interaction between ameloblastoma cells and bone marrow stromal cells (BMSCs) increased the secretion of interleukin (IL)-8 and activin A by BMSCs. Tumor-derived tumor necrosis factor (TNF)- $\alpha$ modulated the expression of IL- 8 in BMSCs. IL-8 could stimulate receptor activator of nuclear factor (NF)- $\mathrm{kB}$ (RANK) ligand (L) in contributing to osteoclast formation. In BMSCs culture, ameloblastoma cells stimulate the secretion of Activin A. The mechanism via cell-to-cellmediated activation of c-Jun $\mathrm{N}$-terminal kinase activation. Osteoclast formation and function were induced by Activin A as a cofactor of RANKL (Liu, et al., 2019). RANKL binding will trigger the activation of the osteoclast. Besides RANKL, the progression also involved matrix metalloproteinases (MMPs). MMP-1, MMP-2, and MMP-9 were released by ameloblastoma (Yoshimoto, et al., 2016). A study confirmed the bone-resorption mechanism of ameloblastoma by observing the role of RANK and MMP-9. On the other hand, osteoprotegerin was found to act as a bone resorption inhibitory factor (Qian and Huang, 2010).

\section{CLINICAL, RADIOGRAPHIC, AND HISTO- LOGICAL FEATURES OF AMELOBLASTOMA}

\section{Clinical Appearance}

In general unicystic, multicystic, dermoplastic, and plexiform ameloblastomas have the same clinical appearances, which are extra and intraoral swelling with the absence of pain (Figueiredo, et al., 2014; Kamboj, et al., 2015). The swelling was the most common symptom (38\%) (Kim and Jang, 2001). The reported initial chief complaint was the swelling of the lower jaw and/ or face, for a period ranging from 1 to 4 months, usually asymptomatic (Figueiredo, et al., 2014). Other rare symptoms experienced by ameloblastoma patients such as local discomfort (11.3\%), purulent discharge $(4.2 \%)$, pain and paresthesia $(1.4 \%)$, tooth mobility (1.4\%), swelling, and purulent discharge (2.8\%) (Kim and Jang, 2001). Sometimes the pain will occur due to hemorrhage in the adjacent soft tissue (Kreppel and Zoller, 2018).

Recurrences have been reported to occur between 2 and 5 years for more than $50 \%$ of the cases. The rest can occur sporadically 20,30 , and even 45 years later. Usually, recurrent lesions were smaller than the primary lesion, and thus, segmental resection may be more limited (Parmar, et al., 2016).

Maxillary ameloblastomas were not commonly found, and approximately about $15 \%$ of 
all ameloblastoma cases. Maxillary ameloblastomas are often be associated with an aggressive course. The surgery challenges are different on maxillary ameloblastoma compare to mandible ameloblastoma. Complication into adjacent spaces such as the maxillary antrum is often detected at later stages of maxillary ameloblastoma (Yang, et al., 2017). If orbital is involved in maxillary ameloblastoma, usually related to high mortality, morbidity, and recurrence. Only 23 well-documented cases and 3 publications in ophthalmic were reported. This indicated the maxillary ameloblastoma was extremely rare. The clinical presentation of recurrent maxillary ameloblastoma such as nasal discharge with blood, swelling, nasal obstruction, pushed-down hard palate, and eye proptosis (Qahtani, et al., 2019).

\section{Radiographic Feature}

Multilocular and unilocular ameloblastomas had the same radiographic features. Well-defined margin, corticated thick, adjacent root resorption may present or absent, buccal/ lingual/inferior border of mandible cortical expansion, and usually found at posterior or anterior of the mandible. Radiographic features of unilocular and multilocular ameloblastomas can be differentiated. The unilocular usually has a smooth shape of margin, absent of septae, and internal structure radiolucent (Figueiredo, et al., 2014). Meanwhile, the multilocular can appears with scalloped margin, thin curved or coarse curved septae, and mix or soap bubble internal radiolucent structure. Radiolucency cyst-like appearance referred to unicystic type ameloblastoma. However, unlike cyst, unicystic ameloblastoma may show trabeculae within the lumen and had a discontinuity in the peripheral cortex. Another radiolucency appearance to be seen is a large radiolucent area with scalloped borders, and it is referred to as one most common appearances of spider-web patterns. From the center of the lumen, coarse strands of trabeculae radiate peripherally, giving rise to a gross caricature of a spider. Multilo- cular radiolucency is seen as a soap bubble pattern. This pattern had a varying size, multi-chambered, or multicystic "bunch of grapes" appearance giving rise to the soap-bubble. The last pattern seen in radiolucency was honeycomb appearance, also known as solid or beehive pattern. The honeycomb appearance arose from multiple small radiolucencies that are seen surrounded by hexagonal or polygonal thick-walled bony cortices (More, et al., 2012).

\section{Histological Findings}

In the WHO classification for odontogenic tumors, types of ameloblastomas are solid/ multicystic, plexiform, and follicular. Other types of ameloblastomas are unicystic, extraosseousperipheral, and desmoplastic (Arora, 2015). Microscopic patterns of ameloblastomas can be uniform or mixed and divided into the follicular, plexiform, acanthomatous, spindle, basal cell-like, desmoplastic, and granular cell. The most common type was the solid or multicystic type with $91 \%$ prevalence of ameloblastoma followed by unicystic, extraosseous, and desmoplastic type with $6 \%$, $2 \%$, and $1 \%$, respectively. Benign ameloblastoma is a unicystic type and divided into intraluminal and intramural subtypes. On the other hand, if the invasion of supporting connective tissue was the intramural subtype. The appearance which is centered within the marrow space and encapsulated by bone was dermoplastic ameloblastoma. The peripheral ameloblastomas are extra-osseous and do not involve the underlying bone (McClary, et al., 2016).

The classical histological pattern of ameloblastoma described by Vickers and Gorlin is characterized by a peripheral layer of tall columnar cells with hyperchromasia, reversely polarized nuclei and sub-nuclear vacuole formation (Masthan, et al., 2015). Follicular type is composed of many small islands of the peripheral layer of cuboidal or columnar cells with a reversely polarized nucleus. The term plexiform refers to the appearance of anastomosing islands of odontogenic epithelium, 
with double rows of columnar cells in a back-toback arrangement. In acanthomatous type, the cells occupying the position of stellate reticulum undergo squamous metaplasia, with keratin pearl formation in the center of tumor islands. In granular cell ameloblastoma, the cytoplasm of stellate reticulum-like cells appears coarse granular and eosinophilic. Basal cell type, the epithelial tumor cells are less columnar and arranged in sheets. The desmoplastic variant is composed of the dense collagen stroma, which appears hypocellular and hyalinised (Rajendran, 2012).

A cyto-histological study investigated the ameloblastoma expression of B-cell lymphoma (Bcl)-2 related proteins. $\mathrm{Bl}-2$ and $\mathrm{Bcl}-\mathrm{x}$ were found more in the outer layer cells of the tumor island. On the other hand, Bcl-2-associated X-protein (Bax) and Bcl2-antagonist/killer (Bak) were found more in the inner layer. This finding indicating the outer layer cell had apoptotic inhibition. Meanwhile, the inner layer cell was experienced more apoptosis (Sandra, et al., 2001). Due to the active proliferating state, Proliferating Cell Nuclear Antigen (PCNA) and $\mathrm{Ki}-67$ of ameloblastoma were investigated. The cytological pattern of ameloblastoma showed PCNA and Ki-67 were expressed in the outer layer. Higher expression of PCNA and Ki-67 suggested the ameloblastoma had a higher proliferation activity in the outer layer (Sandra, et al., 2001).

\section{OSTEOCLASTIC MECHANISM AND ITS UN- DERLYING PATHWAYS IN AMELOBLAS- TOMA}

Bone resorption is a complex process initiated by the proliferation of immature osteoclasts. Osteoclastic differentiation is principally regulated by RANK/RANKL/OPG system. The interaction between RANK and RANKL plays a critical role in promoting osteoclast differentiation and activation, thus leading to bone resorption. RANKL binds to RANK on the surface of preosteoclasts and stimulates the development and activation of osteoclasts. OPG is a soluble decoy receptor for RANKL that blocks osteoclast formation by inhibiting RANKL binding to RANK. The enhanced RANKL expression or decreased OPG levels play an important role in tumor-associated bone destruction (Tekkesin, et al., 2011; Al-Rawi, et al., 2018).

The current concept of bone resorption caused by ameloblastoma occurs as a result of activities by peritumoral osteoclasts. It is believed activation of peritumoral osteoclasts by RANKL is released from the ameloblastoma (Yoshimoto, et al., 2016). RANKL-induced NF- $\kappa \mathrm{B}$ activation for osteoclast differentiation and function. Activated $\mathrm{T}$ cells produce the RANKL that directly controls bone remodeling and osteoclastogenesis. RANKL was expressed in all types of ameloblastomas, and it could be the regulating factor of bone metabolism (Tekkesin, et al., 2011; Sandra, et al., 2005).

Several cytokines such as IL-1, IL-6, IL-8, IL-11, and IL-17 were bone-resorbing factors and have been reported to trigger RANKL expression in BMSCs. Upregulating IL-8 and activin A triggered osteoclastogenesis from the interactions between ameloblastoma cells and BMSCs. Ameloblastoma-derived TNF- $\alpha$ will enhance the production of IL-8 in BMSCs, further induced osteoclast formation directly or by upregulating RANKL expression in BMSCs. The activation of the JNK pathway in the presence of ameloblastoma cells induced stimulation of Activin A secretion in BMSCs. Osteoclast formation and function stimulated by RANKL and activin A acted as a co-factor of RANKL. Overexpression of IL-8 not only correlates with tumor growth, angiogenesis, and metastasis but also serves a critical role in osteoclast formation. Multiple signals, including IL- $1 \alpha$, IL- $1 \beta$, and TNF- $\alpha$, are correlated with the production of IL-8. A study suggested RANKL expression through IL-8-dependent pathway from the interaction between the ameloblastoma cells and BMSCs (Fuchigami, et al., 2014; Liu, et al., 2019). (Figure 1)

Expressions of IL-1 $\alpha$ and IL-6 contribute to the tumor size of ameloblastoma. IL-1 $\alpha$ and IL-6 are known to be the major 
cytokines for osteolysis. Based on the result, the author suggested IL- $1 \alpha$ and IL- 6 mediating bone lysis play a vital role in ameloblastoma expansion in the jawbone (Senguyen, et al., 2011).

Besides RANKL, osteoclastogenesis stimulation by TNF- $\alpha$ has been confirmed. Tartrate-resistant acid phosphatase-positive multinucleated cells formation directly induced by TNF- $\alpha$. This mechanism will produce resorption pits on the bone (Sandra, et al., 2005; Feng, et al., 2019). Besides, matrix metalloproteinases (MMPs) and Cathepsin $\mathrm{K}$ are involved in the degradation of the organic matrix in bone, mainly type I collagen (Qian, et al., 2010).

Regulation of IL-6 and MMP-9 can be modulated by TNF- $\alpha$ in ameloblastoma cells, which implicated the ameloblastoma pathological behavior, such as bone resorption. TNF- $\alpha$ secreted from the tumor directly modulates osteoclasts and may also act on osteoclastogenesis by introducing IL-6 and MMP-9 via autocrine mechanisms in ameloblastoma. TGF- $\beta$ and interferon- $\gamma$ (IFN- $\gamma$ ) have also been reported to be essential regulators of osteoclastogenesis. TGF- $\beta$ is an essential element, as it functions as a cofactor of RANKL. IFN- $\gamma$ has also been shown to induce activation and secretion of the osteoclastogenesis factors. TGF- $\beta$ and IFN- $\gamma$ could increase the levels of TNF- $\alpha$-induced IL-6 and MMP-9. TGF- $\beta$ and IFN- $\gamma$ cooperate to regulate TNF- $\alpha$ mediation of genes related to bone resorption in ameloblastoma cells and may influence ameloblastoma tumor growth and invasiveness. TNF- $\alpha$ was shown to increase NF- $\kappa B$ activation via inhibitor of $\kappa \mathrm{B}(\mathrm{I} \kappa \mathrm{B}) \alpha$ phosphorylation to induce IL-6 and MMP-9, while the NF- $\kappa B$ inhibitor dramatically decreased TNF- $\alpha$-mediated IL-6 and MMP-9 expressions. A study revealed that TNF- $\alpha$-induced NF- $\kappa B$ signaling plays a vital role in pathological behavior, such as bone resorption in ameloblastoma cases. On the opposite, NF- $\mathrm{KB}$ inhibitor blocked TNF- $\alpha$-mediated synergistic induction of MMP-9 and IL- 6 in the presence of IFN- $\gamma$ or TGF- $\beta$. Thus, for NF- $\kappa B$ activation, TNF- $\alpha$ is initially triggered, followed by other signal pathways stimulated by IFN- $\gamma$ or TGF- $\beta$ cross-talk (Ohta, et al., 2017). (Figure 1)

MMPs may contribute to ameloblastoma behavior, which can transduce the Extracellular Related Kinase (ERK) 1/2 pathway. In ameloblastoma, MMPs mediate bone resorption. The tissue inhibitors of metalloproteinases (TIMPs), Transforming Growth Factor (TGF)- $\alpha$, and Epidermal Growth Factor (EGF) cooperate to regulate ameloblastoma proliferation. Distinct signaling pathways have been implicated in TIMP growth-promoting activity, including ERK 1/2. ERK 1/2 signals are generated by growth factors and tissue inhibitors of MMPs (Siqueira, et al., 2010). Besides MMPs, The TN$\mathrm{F}-\alpha$ induction for ameloblastoma was transduced by Phosphoinositide 3-Kinases (PI3K), Akt, and Mitogen-activated Protein Kinase (MAPK). This induction will impact ameloblastoma proliferation activity and survival (Hendarmin, et al., 2005).

RANKL and MMP-9 were found to be immunohistochemically expressed in ameloblastoma. MMP-9 (gelatinase B, a $92 \mathrm{kDa}$ type IV collagenases) is involved in the process of tumor invasion by mediating degradation of basement membrane and remodelling of extracellular matrix (ECM), and one of the most important proteinases involved in bone resorption. MMP-9 is not only contributed to bone matrix degradation but also as a regulator in the initial bone resorption process. MMP-9 presents in ameloblastoma to digest bone matrix and release mitogens, which could increase tumor proliferation (Qian, et al., 2010; Anne, et al., 2014; Pinheiro, et al., 2004).

MMPs and RANKL play important roles in cell proliferation, invasion, and bone resorption. Wnt/ $\beta$-catenin signaling, which is involved in the progression of ameloblastoma, can regulate MMP and RANKL expression. $\beta$-catenin is a key factor in the Wnt signaling pathway, acting as a transcriptional activator. Activation of the Wnt/ $\beta$ catenin pathway inhibits glycogen synthase kinase- $3 \beta$ (GSK-3 $\beta$ ) enzymatic activity within the destruction complex by phosphorylating GSK$3 \beta$ (Yang, et al., 2018). Wnt/ $\beta$-catenin signaling, 
through GSK-3 $\beta$ inactivation, can also affect osteoclast differentiation. Several mechanisms related to $\beta$-catenin signaling are suggested to modulate RANK-RANKL-OPG signaling in osteoclasts (Amirhosseini, et al., 2018). (Figure 1)

Osteoclast differentiation is completed by the expression of a large number of related marker genes, such as MMP-9, Nuclear Factor of Activated
T Cells 1 (NFATc1), TRAP, C-Src, and cathep$\sin \mathrm{K}$. Most of which are target genes of NFATc1. NFATc1 is a well-known master regulator of osteoclastogenesis and function (Sandra, et al., 2005). This osteoclastogenesis provides the space for the ameloblastoma to expand in the bone (Gomes, et al., 2010).

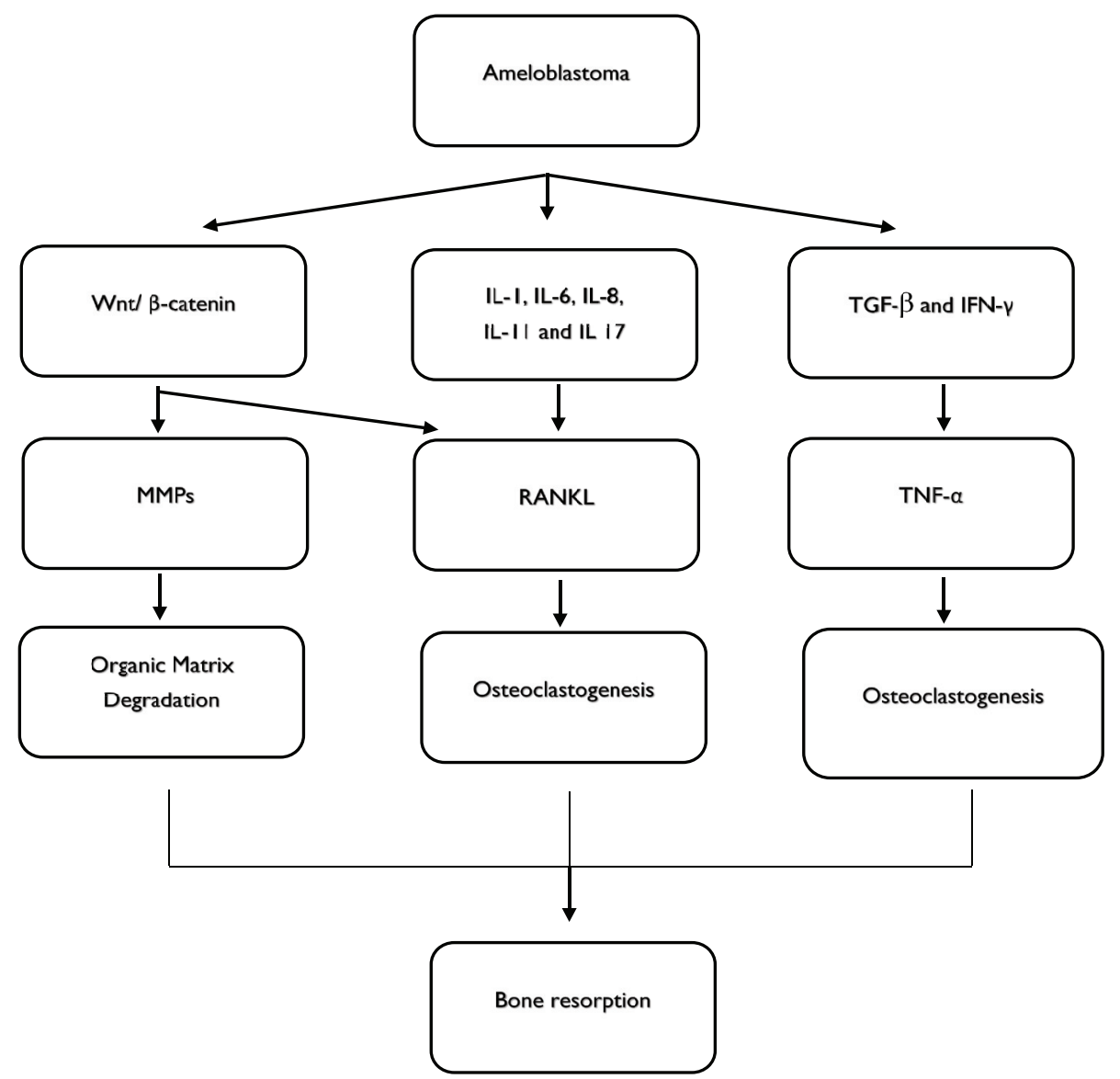

Figure 1. Bone resorption mechanism of ameloblastoma.

\section{MANAGEMENT OF AMELOBLASTOMA AND RECURRENT PREVENTION}

Lesion elimination should always be the main focus for the best treatment choice. The treatment method will influence on the life and rehabilitation of the patients. Treatment options ranging from conservative to radical bone resections (Maia and Sandrini, 2017).
MMP-2 and MMP-9 are proteolytic enzymes and target genes of Wnt pathways. Both MMPs mediate tumor growth and invasion by regulating events like neoangiogenesis, antiapoptosis, invasion, and metastasis. The elevated neovascularization or angiogenesis indicated the tumor prone to recurrence. Each type of ameloblastoma had the variant expression of the MMPs. High expression of MMPs was reported to be correlated 
with the high proliferative ameloblastoma with elevated neoangiogenesis. Therefore, adequate treatment with more extensive resection should be considered. In contrast, lower expression of these markers suggests the treatment could be done with the conservative procedure (Kibe, et al., 2013; Sah, et al., 2013). (Figure 2)

MMPs role of action is mainly the degradation of ECM. While RANKL is involved in the mechanism of how the tumor expands in the bone, RANKL is required for osteoclast development. Therefore, target therapy on these markers could be potential (Al-Rawi, et al., 2018). Invasion by ameloblastoma cells expressing RANKL, marked by a larger tumor volume, needs more invasive procedures, such as segmental resection with the discontinuity of the bone piece, even removing the periosteum, and overlying soft tissue (Dissanayake et al., 2011). (Figure 2)

Conservative methods such as enucleation and curettage require less operation time, but these methods are assumed to be associated with high recurrence rates and re-resection (Hendra, et al., 2019). Recurrence rates of solid and unicystic ameloblastomas revealed a lower risk of recurrence after radicalization compared to conservative treatment (Antonoglou and Sandor, 2015). Recurrence rates were 3\% for radical treatment and $21 \%$ for conservative treatment. The solid or multicystic ameloblastoma may behave more aggressively than the unicystic ameloblastoma based on the recurrence rates (Hendra, et al., 2019). Despite the surgery, another important aspect is the awareness of the patients since they will

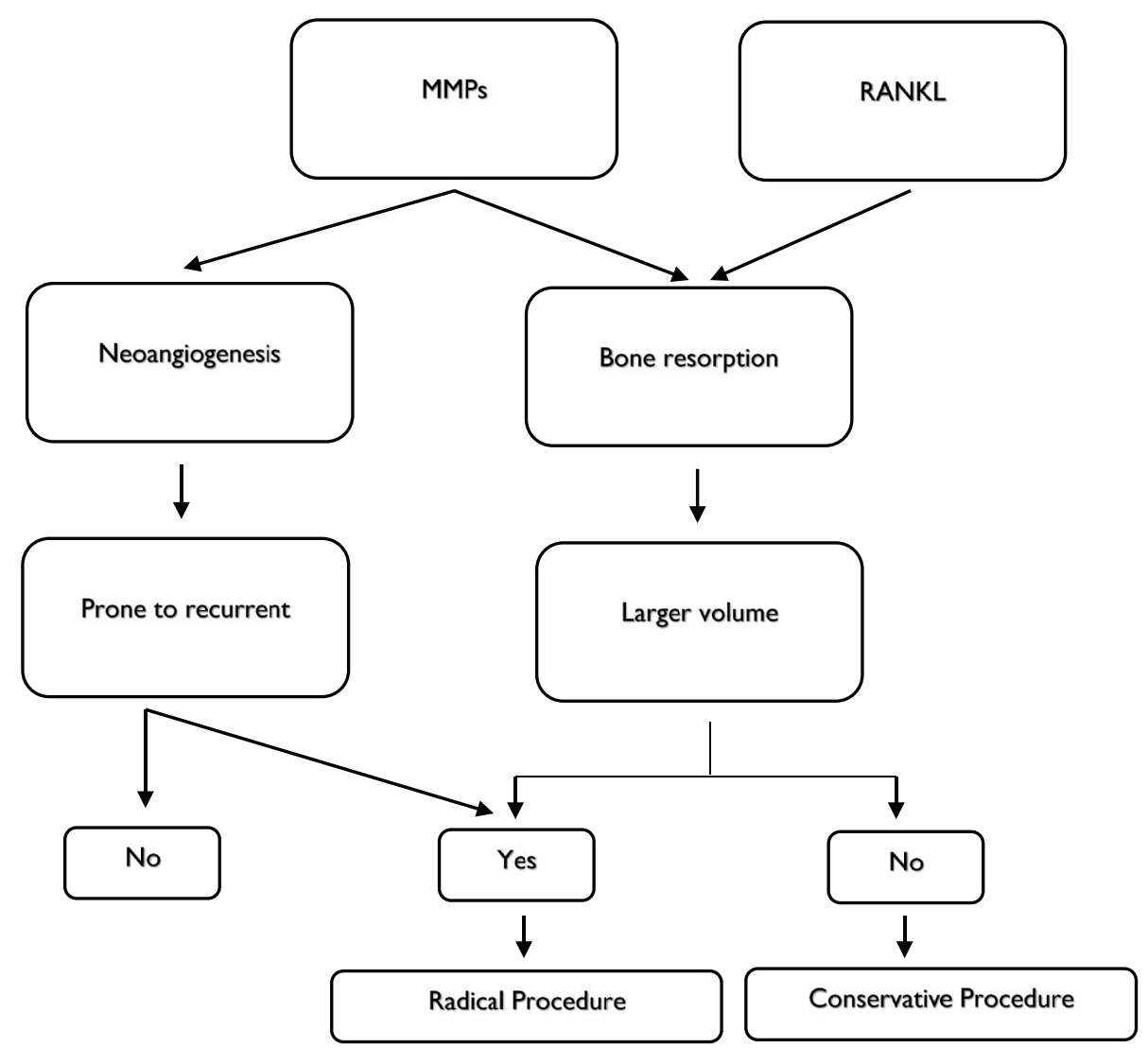

Figure 2. Procedure selection for ameloblastoma based on bone expansion and recurrent prevention. 
need more rigorous attention and care regarding their oral health, including specific diet, follow-up, and periodical examinations. (França, et al., 2012).

\section{CONCLUSION}

Bone resorption in ameloblastoma occurs as a result of peritumoral osteoclasts activities. Osteoclastic induction of ameloblastoma cells is associated with RANKL, TNF- $\alpha$, and MMPs. RANKL expression will induce osteoclast differentiation and function. TNF- $\alpha$ induces osteoclast formation and modulates the regulation of MMPs. While MMPs, despite mediating degradation of the basement membrane, also play a role in and neovascularization event. By understanding the osteoclastogenesis in ameloblastoma cases, together with surgery and other target therapies, the RANKL, TNF- $\alpha$, and MMPs should be targeted so that the growth and recurrence of ameloblastoma can be managed.

\section{REFERENCES}

Al-Rawi, N.H., Al-Siraj, A.K. and Majeed, A.H., 2018, Comparison of osteoclastogenesis and local invasiveness of ameloblastoma keratocystic odontogenic tumor, Eur. J. Dent., 12(1), 36-42.

Amirhosseini, M., Madsen, R.V., Escott, K.J., Bostrom, M.P., Ross, F.P. and Fahlgren, A., 2018, GSK-3B Inhibition Suppresses Instability-induced Osteolysis by a Dual Action on Osteoblast and Osteoclast Differentiation, J. Cell. Physiol., 233(3), 2398-2408.

Anne, R., Krisnuhoni, E., Chotimah, C. and Latief, B.S., 2014, Matrix metalloproteinase-9 (MMP-9) expression in different subtypes of ameloblastoma, J. Maxillofac. Oral. Surg., 13(3), 281285.

Antonoglou, G.N. and Sandor, G.K., 2015, Recurrence rates of intraosseous ameloblastomas of the jaws: A systematic review of conservative versus aggressive treatment approaches and metaanalysis of non-randomized studies, Journal of
Cranio-Maxillo-Facial Surgery, 43(1), 149-157.

Arora, S., 2015, Unicystic ameloblastoma: A perception for the cautious interpretation of radiographic and histologic findings, J. Coll. Physician. Surg. Park., 25(10), 761-764.

Brown, N.A., Betz, B.L., Weigelin, H.C., ElenitobaJohnson, K.S., Lim, M.S. and Bailey, N.G., 2015, Evaluation of allele-specific PCR and immunohistochemistry for the detection of BRAF V600E mutations in hairy cell leukemia, Am. J. Clin. Pathol., 143(1), 89-99.

Dissanayake, R.K., Jayasooriya, P.R., Siriwardena, D.J. and Tilakaratne W.M., 2011, Review of metastasizing (malignant) ameloblastoma (METAM): pattern of metastasis and treatment, Oral. Surg. Oral. Med. Oral. Pathol. Oral. Radiol. Endod., 111(6), 734-41.

Effiom, O.A., Ogundana, O.M., Akinshipo, A.O. and Akintoye, S.O., 2018, Ameloblastoma: current etiopathological concepts and management, Oral. Diseases., 24(3), 307-316.

Feng, W., Guo, J. and Li, M., 2019, RANKL-independent modulation of osteoclastogenesis, J. Oral. Biosci, 61(1), 16-21.

Figueiredo, N.R., Dinkar, A.D., Meena, M., Sujata, S. and Manisha, K., 2014, Ameloblastoma: A clinicoradiographic and histopathologic correlation of 11 cases seen in Goa during 2008-2012, Contemp. Clin. Dent., 5(2), 16-165.

França, L.J., Curioni, O.A., Paiva, D.L., Vianna, D.M., Dedivitis, R.A. and Rapoport, A., 2012, Ameloblastoma demographic, clinical, and treatment study: analysis of 40 cases, Braz. J. Otorhinolaryngol., 78(3), 38-41.

Fuchigami, T., Kibe, T., Koyama, H., Kishida, S., lijima, M., Nishizawa, Y., et al., 2014, Regulation of IL-6 and IL-8 production by reciprocal cell-to-cell interactions between tumor cells and stromal fibroblasts through IL-1a in ameloblastoma, Biochem. Biophys. Res. Commun., 451, 491-496.

Gomes, C.C., Duarte, A.P., Diniz, M.G. and Gomez, R.S., 2010, Current concepts of ameloblastoma 
pathogenesis, J. Oral. Pathol. Med., 39, 585591.

Hendra, F.N., Natsir-Kalla, D.S., Van-Cann, E.M., de-Vet, H., Helder, M.N. and Forouzanfar, T., 2019, Radical vs. conservative treatment of intraosseous ameloblastoma: Systematic review and meta-analysis, Oral. Diseases., 25(7), 1683-1696.

Hendarmin, L., Sandra, F., Nakao, Y., Ohishi, M. and Nakamura, N., 2005, TNFalpha played a role in the induction of Akt and MAPK signals in ameloblastoma, Oral. Oncol., 41(4), 375-82.

Intapa, C., 2017, Analysis of Prevalence and Clinical Features of Ameloblastoma and its Histopathological Subtypes in Southeast Myanmar and Lower Northern Thailand Populations: A 13-Year Retrospective Study, J. Clin. Diagn. Res., 11(1), ZC102-ZC106.

Kamboj, M., Shreedhar, B. and Chaturvedi, M., 2015, Plexiform unicystic ameloblastoma: A case report and data analysis in the Indian population, J. Maxillofac. Oral. Surg., 14(1), 407-411.

Kibe, T., Fuchigami, T., Kishida, M., lijima, M., Ishihata, K., Hijioka, H., et al., 2013, A novel ameloblastoma cell line (AM-3) secretes MMP9 in response to Wnt-3a and induces osteoclastogenesis, Oral. Surg. Oral. Med. Oral. Pathol. Oral. Radiol., 115(6), 780-788.

Kim, S. and Jang, H., 2001, Ameloblastoma: A clinical, radiographic, and histopathologic analysis of 71 cases, Oral. Surg. Oral. Med. Oral. Pathol. Oral. Radiol. Endod., 91, 649-653.

Kreppel, M. and Zoller, J., 2018, Ameloblastomaclinical, radiological, and therapeutic findings, Oral. Dis., 24(1-2), 63-66.

Liu, X., Chen, Z., Lan, T., Liang, P. and Tao, Q., 2019, Upregulation of interleukin- 8 and activin $A$ induces osteoclastogenesis in ameloblastoma, Int. J. Mol. Med., 43(6), 2329-2340.

Maia, E.C. and Sandrini, F.A.L., 2017, Management techniques of ameloblastoma: a literature review, RGO. Rev. Gaúch. Odontol., 65(1), 62-69. Masthan, K., Anitha, N., Krupaa, J., Manikkam, S.,
2015, Ameloblastoma, J. Pharm. Bioall. Sci., 7, 167-70.

McClary, A.C., West, R.B., McClary, A.C., Pollack, J.R., Fischbein, N.J., Holsinger, C.F., et al., 2016, ameloblastoma: a clinical review and trends in management, Eur. Arch. Otorhinolaryngol., 273(7), 1649-1661.

More, C., Tailor, M., Patel, H.J., Asrani, M., Thakkar, K. and Adalja, C., 2012, Radiographic analysis of ameloblastoma: a retrospective study, Indian. J. Dent. Res., 23(5), 698.

Ohta, K., Naruse, T., Ishida, Y., Shigeishi, H., Nakagawa, T., Fukui, A., et al., 2017, TNF-a-induced IL-6 and MMP-9 expression in immortalized ameloblastoma cell line established by hTERT, Oral. Dis., 23(2), 199209.

Parmar, S., Al-Qamachi, L. and Aga, H., 2016, Ameloblastomas of the mandible and maxilla, Curr. Opin. Otolaryngol. Head. Neck. Surg., 24, 148-154.

Petrovic, I.D., Migliacci, J., Ganly, I., Patel, S., Xu, B. and Ghossein, R., et al., 2018, Ameloblastomas of the mandible and maxilla, Ear. Nose. Throat. J., 97(7), E26-E32.

Pinheiro, J.J.V., Freitas, V.M., Moretti, A.I.S., Jorge, A.G., Jaeger, R.G., 2004, Local invasiveness of ameloblastoma. Role played by matrix metalloproteinases and proliferative activity, Histopathology., 45, 65-72.

Qahtani, K.A.L., Alkhudhayri, A.F., Islam, T., Mufargi, K.A.L., Shakweer, W.A.L. and Otaibi, F., 2019, Recurrent unicystic maxillary ameloblastoma presenting as unilateral proptosis, Saudi. J. Ophthalmol., 33(1), 94-98.

Qian, Y. and Huang, H.Z., 2010, The role of RANKL and MMP-9 in the bone resorption caused by ameloblastoma, J. Oral. Pathol. Med., 39(8), 592-598.

Rajendran, R., 2012, cyst and tumors of odontogenic origin. In: Rajendran R, Sivapathasundharam B, ed., 2012, Shafer's Text Book of Oral Pathology, $7^{\text {th }}$ ed. Indian: Elsevier. pp. 259-313. 
Ruslin, M., Hendra, F.N., Vojdani, A., Hardjosantoso, D., Gazali, M., Tajrin, A., et al., 2018, The Epidemiology, treatment, and complication of ameloblastoma in East-Indonesia: 6 years retrospective study, Med. Oral. Patol. Oral. Cir. Bucal., 23(1), e54-e58.

Saghravanian, N., Salehinejad, J., Ghazi, N., Shirdel, M. and Razi, M., 2016, A 40-year Retrospective Clinicopathological Study of Ameloblastoma in Iran, Asian. Pac. J. Cancer. Prev., 17(2), 619623.

Sah, P., Menon, A., Kamath, A., Chandrashekar, C., Carnelio, S. and Radhakrishnan, R., 2013, Role of immunomarkers in the clinicopathological analysis of unicystic ameloblastoma, Dis. Markers., 35(5), 481-488.

Sandra, F., Hendarmin, L., Kukita, T., Nakao, Y., Nakamura, N. and Nakamura, S., 2005, Ameloblastoma induces osteoclastogenesis: a possible role of ameloblastoma in expanding in the bone, Oral. Oncol., 41(6), 637-644.

Sandra, F., Nakamura, N., Mitsuyasu, T., Shiratsuchi, Y. and Ohishi, M., 2001, Two relatively distinct patterns of ameloblastoma: an anti-apoptotic proliferating site in the outer layer (periphery) and a pro-apoptotic differentiating site in the inner layer (center), Histopathology., 39(1), 93-98.

Sandra, F., Mitsuyasu, T., Nakamura, N., Shiratsuchi, Y. and Ohishi, M., 2001, Immunohistochemical evaluation of PCNA and Ki-67 in ameloblastoma, Oral. Oncol., 37(2),193-8.

Senguyen, B. and Oygur, T., 2011, Investigation of interleukin-1 alpha and interleukin-6 expression and interleukin-1 alpha gene polymorphism in keratocystic odontogenic tumor and ameloblastomas, Med. Oral. Patol. Oral. Cir. Bucal., 16(4), 467-72.
Singh, T., Wiesenfeld, D., Clement, J., Chandu, A. and Nastri, A., 2015, Ameloblastoma: demographic data and treatment outcomes from Melbourne, Australia, Aust. Dent. J., 60(1), 24-29.

Siqueira, A.S., Carvalho, M.R.D., Monteiro, A.C.D., Freitas, V.M., Jaeger, R.G. and Pinheiro, J.J.V., 2010, Matrix metalloproteinases, TIMPs and growth factors regulating ameloblastoma behavior, Histopathology., 57(1), 128-37.

Sun, T., Yang, W., Toprani, S. M., Guo, W., He, L., Deleo, A.B., et al., 2020, Correction to Induction of immunogenic cell death in radiation-resistant breast cancer stem cells by repurposing anti-alcoholism drug disulfiram, Cell. Commun. Signal., 18(1), 53.

Tekkesin, M.S., Mutlu, S. and Olgac, V., 2011, The role of RANK/RANKL/OPG signaling pathways in osteoclastogenesis in odontogenic keratocysts, radicular cysts, and ameloblastomas, Head. Neck. Pathol., 5(3), 248-253.

Toprani, S.M., 2020, DNA damage and repair scenario in ameloblastoma, Oral. Oncol., 108, 104804.

Yang, R., Liu, Z., Peng, C., Cao, W. and Ji, T., 2017, Maxillary ameloblastoma: Factors associated with risk of recurrence, Head. \& Neck., 39(5), 996-1000.

Yang, Z., Li, K., Liang, Q., Zheng, G., Zhang, S., Lao, X., et al., 2018, Elevated hydrostatic pressure promotes ameloblastoma cell invasion through upregulation of MMP-2 and MMP-9 expression via Wnt/B-catenin signaling, J. Oral. Pathol. Med., 47(9), 836-846.

Yoshimoto, S., Morita, H., Matsubara, R., Mitsuyasu, T., Imai, Y., Kajioka, S., et al., 2016, Surface vacuolar ATPase in ameloblastoma contributes to tumor invasion of the jaw bone, Int. J. Oncol., 48(3), 1258-1270. 

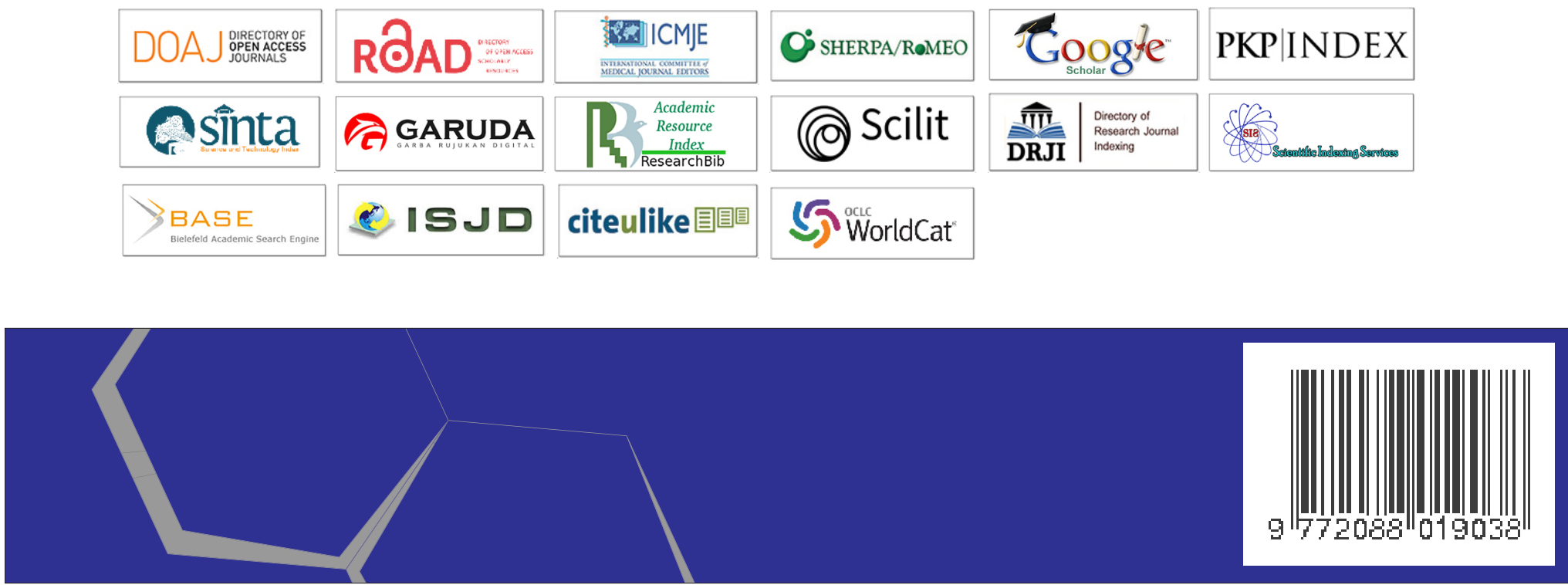